San Jose State University

SJSU ScholarWorks

Master's Theses

Master's Theses and Graduate Research

1992

\title{
An examination of the relationship between achievement in solving process problems and cognitive levels of development in third-grade students
}

Sunny Chen

San Jose State University

Follow this and additional works at: https://scholarworks.sjsu.edu/etd_theses

\section{Recommended Citation}

Chen, Sunny, "An examination of the relationship between achievement in solving process problems and cognitive levels of development in third-grade students" (1992). Master's Theses. 450.

DOI: https://doi.org/10.31979/etd.mrta-s9z4

https://scholarworks.sjsu.edu/etd_theses/450

This Thesis is brought to you for free and open access by the Master's Theses and Graduate Research at SJSU ScholarWorks. It has been accepted for inclusion in Master's Theses by an authorized administrator of SJSU ScholarWorks. For more information, please contact scholarworks@sjsu.edu. 


\section{INFORMATION TO USERS}

This manuscript has been reproduced from the microfilm master. UMI films the text directly from the original or copy submitted. Thus, some thesis and dissertation copies are in typewriter face, while others may be from any type of computer printer.

The quality of this reproduction is dependent upon the quality of the copy submitted. Broken or indistinct print, colored or poor quality illustrations and photographs, print bleedthrough, substandard margins, and improper alignment can adversely affect reproduction.

In the unlikely event that the author did not send UMI a complete manuscript and there are missing pages, these will be noted. Also, if unauthorized copyright material had to be removed, a note will indicate the deletion.

Oversize materials (e.g., maps, drawings, charts) are reproduced by sectioning the original, beginning at the upper left-hand corner and continuing from left to right in equal sections with small overlaps. Each original is also photographed in one exposure and is included in reduced form at the back of the book.

Photographs included in the original manuscript have been reproduced xerographically in this copy. Higher quality $6 "$ " 9 9" black and white photographic prints are available for any photographs or illustrations appearing in this copy for an additional charge. Contact UMI directly to order.

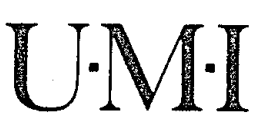



Order Number 1351021

An examination of the relationship between achievement in solving process problems and cognitive levels of development in third-grade students

Chen, Sunny Hui-Shan, M.A.

San Jose State University, 1992 


\title{
AN EXAMINATION OF THE RELATIONSHIP BETWEEN ACHIEVEMENT IN SOLVING PROCESS PROBLEMS AND COGNITIVE LEVELS OF DEVELOPMENT IN THIRD-GRADE STUDENTS
}

\author{
A Thesis \\ Presented to \\ The Faculty of the College of Education \\ San Jose State University \\ In Partial Fulfillment \\ of the Requirements for the Degree \\ Master of Arts
}

by

Sunny Chen

December 1992 


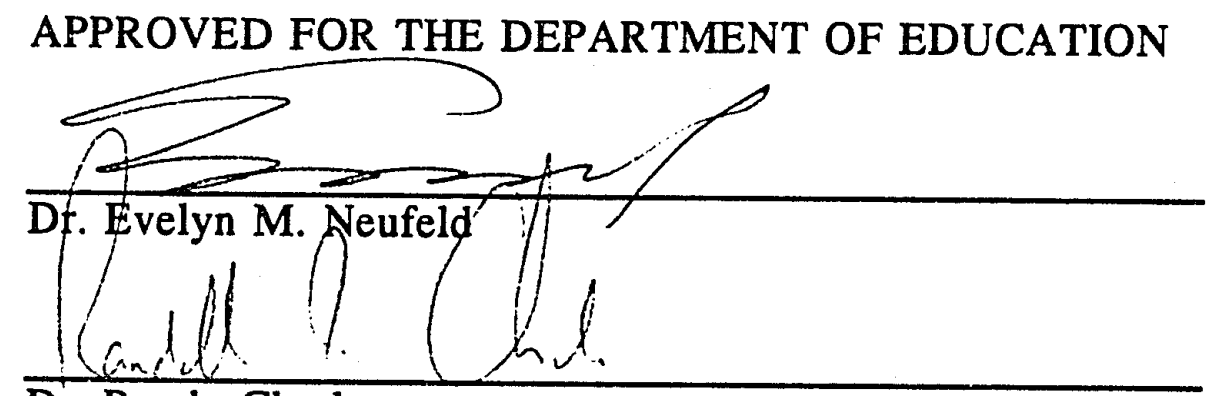

Dr. Randy Charles

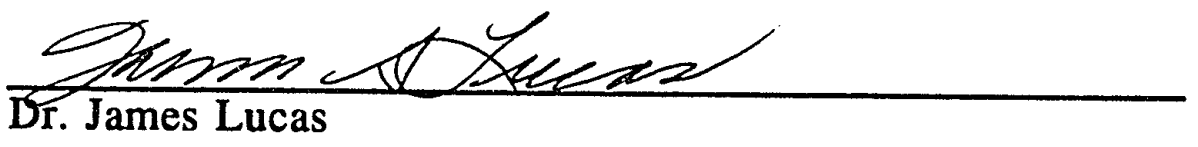

APPROVED FOR THE UNIVERSITY

M. In Sewandoneh. 


\section{ABSTRACT \\ AN EXAMINATION OF THE RELATIONSHIP BETWEEN ACHIEVEMENT IN SCLVING PROCESS PROBLEMS AND COGNITIVE LEVELS OF DEVELOPMENT IN THIRD-GRADE STUDENTS}

\section{By Sunny Chen}

This study examined the relationship between students' problemsolving ability and their cognitive level of development. Twenty students in the third grade were the subjects for this study. Twelve process problems were administered to subjects in order to determine their problem-solving ability. Seven Piagetian tasks were administered individually to each subject to determine the cognitive level of development. Correlational analyses showed a significant positive relationship between students' achievement in solving process problems and their performance on Piagetian tasks. Students who scored high in Piagetian tasks tended to have high scores in process problems. A positive relationship existed between students' problem-solving ability and their cognitive level of development. 


\section{ACKNOWLEDGEMENTS}

Dedicated to My Parents, Richard and Sumi

I would like to express my gratitude to the following people for their assistance and encouragement in the preparation of my Masters thesis. My thanks go to my advisor, Dr. Neufeld, for her critical comments and valuable suggestions; to $\mathrm{Dr}$. Charles for his advice, and especially for the sources which he provided on the issue of problem-solving; to Dr. Lucas for his help on the statistical procedure for this thesis; and to Mr. Richard Trentton for offering generous help in the process of the testing. I would also like to thank Marcia Morton for her assistance with editing and word processing.

Finally, I would especially like to express my gratitude to my parents, to whom this thesis is dedicated, for their encouragement and affection. I am most indebted to my husband, Paul, for his love, understanding, and support, and certainly to my little son who was so understanding that he began to sleep through the night when he was only two months old so that I could concentrate on my paper! Without the inspiration and support of my wonderful family, I can't imagine how I could have ever completed this thesis and, at the same time, managed the responsibilities of motherhood. 
TABLE OF CONTENTS

Page

LIST OF FIGURES $\ldots \ldots \ldots \ldots \ldots \ldots \ldots \ldots \ldots$ vii Chapter

I. INTRODUCTION $\ldots \ldots \ldots \ldots \ldots \ldots \ldots \ldots \ldots$

Background . . . . . . . . . . . . . . . 1

Word Problems $\ldots \ldots \ldots \ldots \ldots \ldots \ldots \ldots \ldots \ldots$

Translation Problems $\ldots \ldots \ldots \ldots \ldots \ldots \ldots$

Process Problems ................. 4

Factors Affecting Problem-Solving Performance ....... 6

The Role of Teachers $\ldots \ldots \ldots \ldots \ldots \ldots \ldots$

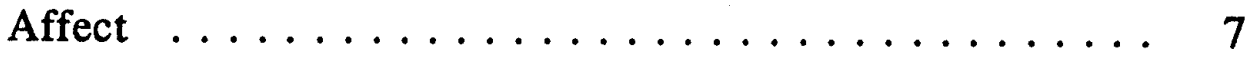

Cognitive Development . . . . . . . . . . 7

Piaget's Theory of Cognitive Development $\ldots \ldots \ldots \ldots$

Statement of the Problem $\ldots \ldots \ldots \ldots \ldots \ldots$

Statement of Purpose $\ldots \ldots \ldots \ldots \ldots \ldots \ldots$

Operational Definitions . . . . . . . . . . . . . . 11

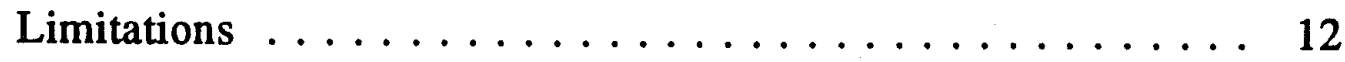

II. REVIEW OF THE LITERATURE $\ldots \ldots \ldots \ldots \ldots \ldots \ldots$

Translation Problems Versus

Word Problems $\ldots \ldots \ldots \ldots \ldots \ldots \ldots \ldots \ldots$ 
Factors Affecting Problem-Solving Performance . . . . . 17

The Role of the Teacher $\ldots \ldots \ldots \ldots \ldots \ldots$

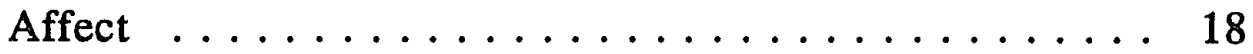

Cognitive Development . . . . . . . . . . . . 19

Piaget's Theory of Cognitive Development $\ldots \ldots \ldots \ldots 23$

Levels of Development $\ldots \ldots \ldots \ldots \ldots \ldots$

Factors Affecting Cognitive Development $\ldots \ldots \ldots 26$

Summary $\ldots \ldots \ldots \ldots \ldots \ldots \ldots \ldots \ldots \ldots$

III. METHODOLOGY $\ldots \ldots \ldots \ldots \ldots \ldots \ldots \ldots \ldots$

Subjects $\ldots \ldots \ldots \ldots \ldots \ldots \ldots \ldots \ldots \ldots \ldots$

Tools and Instruments $\ldots \ldots \ldots \ldots \ldots \ldots \ldots$

Procedures for Collection of Data . . . . . . . . . . 32

Data Analysis .................... 33

IV. ANALYSIS OF DATA $\ldots \ldots \ldots \ldots \ldots \ldots \ldots$

Introduction $\ldots \ldots \ldots \ldots \ldots \ldots \ldots \ldots \ldots \ldots$

Results $\ldots \ldots \ldots \ldots \ldots \ldots \ldots \ldots \ldots \ldots \ldots \ldots$

Summary of Results . . . . . . . . . . . . 45

V. SUMMARY AND CONCLUSIONS $\ldots \ldots \ldots \ldots \ldots \ldots$

Results ..................... 50

Discussion $\ldots \ldots \ldots \ldots \ldots \ldots \ldots \ldots \ldots \ldots \ldots$

Recommendations $\ldots \ldots \ldots \ldots \ldots \ldots \ldots \ldots$

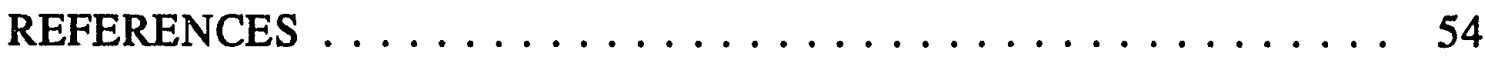

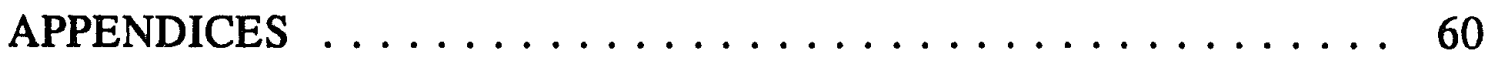




\section{LIST OF FIGURES}

Page

Figures (Scattergrams)

1. Number sense and process

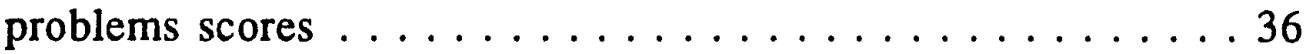

2. Logic operations and process problems scores $\ldots \ldots \ldots \ldots \ldots \ldots \ldots \ldots \ldots \ldots$

3. Spatial concepts and process problems scores $\ldots \ldots \ldots \ldots \ldots \ldots \ldots \ldots \ldots \ldots$

4. Seriation and process problems scores $\ldots \ldots \ldots \ldots \ldots \ldots \ldots \ldots \ldots$

5. Conservation of weight and process problems scores $\ldots \ldots \ldots \ldots \ldots \ldots \ldots$

6. Conservation of volume and process problems scores $\ldots \ldots \ldots \ldots \ldots \ldots \ldots$

7. Conservation of length and process problems scores $\ldots \ldots \ldots \ldots \ldots \ldots 4$

8. Total Piagetian tasks scores and process problems scores $\ldots \ldots \ldots \ldots \ldots \ldots$ 
Chapter I

\section{INTRODUCTION}

Problem solving, as a major mathematics curricular emphasis, resurfaced as a goal in mathematics education in the late 1970's with focused attention arising from An Agenda for Action (1980), published by the National Council of Teachers of Mathematics (NCTM). Local, state, and national professional organizations stress that in this time of increasing use of technology, it is important for students to learn how to face the challenges of a great variety of situations (Krulik \& Rudnik, 1987). The California Assessment Program (1980) recommended "that time and effort be redirected from drill and practice on computation to the development of problem-solving strategies" (p. 210). The National Assessment of Educational Progress (1983) reported that assessment of student achievement suggests that American students are falling behind the students of other nations in problem-solving skills. The ultimate goal of mathematical problem solving is to enable students to think for themselves (Lester, 1985).

\section{Background}

What is problem solving? According to the National Council of Teachers of Mathematics (1968), "a true problem in mathematics can be thought of as a situation that is novel for the individual called upon to solve it" (p. 477). According to Lester (1980), problem solving includes a set of actions taken to perform a task for which there is no readily apparent algorithm for reaching the solution. Stanic and Kilpatrick 
(1988) define problem solving as a set of actions to reach a goal when the direct route to the goal is blocked. Mathematics Framework (California State Department of Education, 1985) also defines problem solving as "applying one's knowledge, skills, and experience in efforts to resolve new or perplexing situations" (p. 2).

There are some conditions to determine whether a problem is a true problem for a particular individual (NCTM, 1968):

1. The individual has a clearly defined, desired goal, of which he is consciously aware.

2. The path to the goal is blocked, and the individual's fixed patterns of behavior, his habitual responses, are not sufficient for removing the block.

3. Deliberation must take place. The individual becomes aware of the problem, defines it more or less clearly, identifies various possible hypotheses (solutions), and tests these for feasibility (p. 478).

In solving the problem, it is important that an individual understands what question is being asked and that there is a desire to attain a solution. Different kinds of problem-solving behaviors, such as "observing, exploring, decision-making, organizing, recognizing, remembering . . ., guessing, classifying, formulating, generalizing" (NCTM, 1968, p. 479) will be exhibited by individuals in the process of solving true problems. According to the NCTM 30th yearbook (1968), "most of the textbook examples in mathematics do not call for many of these behaviors on the part of the students. Rather, their solution depends almost entirely on simple recall" (p. 479). 
Twenty-five years later, problem solving is still the main issue in the mathematics education community. According to Stanic and Kilpatrick (1988), problem solving helps students connect mathematical concepts with real world experiences and can motivate students to learn mathematics. Problem solving is treated as a vehicle, as well as a practice, to help students learn mathematical skills and concepts. Furthermore, problem solving helps students develop reasoning abilities and discover the beauty of mathematics.

According to Mayer (1977), problem-solving activities range from chess, to geometry, to word problems. These activities help students become involved in different types of problem-solving experiences. Even though problem solving encompasses more than solving word problems, this study was limited to word problems.

Word Problems

According to the NCTM 30th Yearbook, "word problems - problems that are written or stated in English sentences - are a useful device for teaching problem solving" (1968, p. 480). According to Charles and Lester (1985), in most elementary mathematics textbooks, word problems can be grouped into two categories: translation problems and process problems. 1. Translation Problems

Translation problems emphasize translating from word problems to number sentences to reach solutions.

There are two types of translation problems: simple translation and complex translation problems. Simple translation problems are also called 
"one step" problems, because only one operation is required for their solution. An example of a simple translation problem is:

Jennifer is 12 years old. Jennifer is 3 years older than her sister, Nel. How old is Nel? (Charles \& Lester, 1984, p. 5)

The solution of this problem requires translating these words into a subtraction number sentence.

Complex translation problems, or "multiple step" problems, require more than one operation to reach the solution. An example of a complex translation problem is:

Yolanda makes $8 \notin$ on each school newspaper she sells. She has sold 9 papers so far. How much more money does she need to earn to buy

a pen that costs $\$ 1$ ? (p. 74)

The solution to this problem requires using the operations of multiplication and subtraction.

\section{Process Problems}

Process problems, sometimes called nonroutine problems, or "unusual" problems (NCTM, 1968, p. 500), cannot be solved by simply translating word problems into one or more number sentences. An example of a process problem is:

Mindy is older than Joanie. Joanie is younger than Wendy. Who is the youngest? (p. 48)

In order to sort out the age order of three people, logical thinking is required. Unlike translation problems, there is no number sentence that can represent this word problem.

According to NCTM (1968), process problems "will not lend themselves to the immediate writing and subsequent solution of 
mathematical sentences" (p. 500). The goal of these kinds of problems is to have students "discover and generate the solution from certain given information" (p. 501). According to Charles, Mason, and White (1982), process problems emphasize "(a) understanding the problem, (b) developing and carrying out a solution strategy, and (c) evaluating the solution" (p. 74). As stated earlier, they call for different kinds of problem-solving behaviors, such as formulating, generalizing, guessing, and organizing on the part of the students (NCTM, 1968).

According to the Curriculum and Evaluation Standards for School Mathematics (1989), "a major goal of problem-solving instruction is to enable children to develop and apply strategies to solve problems" (p. 24.) Process problems emphasize thinking and applying strategies for obtaining problem solutions (Charles \& Lester, 1985). Skemp (1978) called it "relational understanding." He suggested that mathematics should build upon a conceptual structure. Students could then produce an unlimited number of plans to start from any point of the problem situation and be able to reach the final solution. Piaget (1970) also pointed out that "the essential aspect of thought is its operative and not its figurative aspect" (p. 15). The operative aspect of thought is the transformation of actions to the level of reversibility. On the other hand, the figurative aspect of thought is static.

In solving process problems, individuals often engage in different types of problem-solving behaviors and have to use logical thinking and reasoning skills to reach the solution. Therefore, as stated in the NCTM 30th Yearbook (1968), process problems constitute a better representation 
of true problems for students than do translation problems. This study used process problems to measure students' problem-solving ability.

Factors Affecting Problem-Solving Performance

Some of the factors that have been shown to affect problem-solving performance are the teacher, the students' level of affectivity, and the students' level of cognitive development (Silver 1985; McLeod, 1988). The Role of Teachers

The role of the teacher in problem-solving instruction directly affects students' performance. For a teacher to help students improve their problem-solving abilities, "it is necessary to identify (a) which processes subjects use naturally, (b) when they acquire these capabilities, and (c) which processes they can be taught to use in order to maximize instructional effectiveness" (Lester, 1980, p. 295). Furthermore, it is important to understand the features of various problems that require children at different stages of development to produce an appropriate understanding of the problems in order to solve the problems (Riley, Greeno, \& Heller, 1983).

According to Peterson, Carpenter, and Fennema (1989), teachers' knowledge of their students' problem-solving abilities are positively related to students' problem-solving achievement. Teachers with more knowledge of their students question students about problem-solving processes and listen to their responses; on the other hand, teachers with less knowledge of their students tend to explain the problem-solving process to students. Thus, the more teachers know about their students' abilities, the more effective their instruction will be. 


\section{$\underline{\text { Affect }}$}

Students' attitudes toward problem solving can be determinants in their success with problem solving. Students often report feelings of frustration or satisfaction when they work on process problems (McLeod, 1988). Also, McLeod found that the belief which students had in their own capabilities with respect to the solving of process problems determined their willingness to persevere in a problem-solving task. Schoenfeld (1985) found that students tend to believe that if they cannot solve word problems in less than 10 minutes, they will be unable to solve them at all.

According to Piaget (1968), "there is a close parallel between the development of affectivity and that of the intellectual functions, since these are two indissociable aspects of every action" (p. 33). For Piaget, there is never a purely cognitive action, nor a purely affective action (Piaget, 1968). Therefore, in the process of problem solving, one would expect a close relationship between the act of solving problems and affective factors.

\section{Cognitive Development}

It is important to understand the prerequisite structures necessary for solving certain problems, as well as how to adapt different strategies for teaching at different levels (Nesher, Greeno, \& Riley, 1982). The study of Nesher et al. (1982) analyzed the difficulties that children encounter at different levels of cognition. They have suggested four developmental levels that could account for children's performance of word problems involving addition and substraction at various ages. The four 
developmental levels are: (a) ability to identify sets by various verbal description; (b) ability to link events by cause and effect; (c) reversibility of part-part-whole schema; and (d) reversibility of non-symmetrical relations.

Younger children tend to focus on irrelevant attributes of a problem situation (Stevenson, 1975). Bana and Nelson (1978) investigated the effects of "distractors" in different problem settings on the problem-solving behavior of children in grades 1-3. The following four types of distractors were randomly assigned to the problems: (a) minimal distraction, (b) situational distraction, (c) color-attribute distraction, and (d) spatialnumber distraction. The problem was then presented verbally to the subjects. The subjects were required to give a solution and were asked how they would solve the problem. They found that irrelevant data do affect children's problem-solving performance, and spatial-numerical distractions appeared to be the strongest.

Piaget's Theory of Cognitive Development

According to Piaget (1968), cognitive level of development progresses through four distinct stages:

The stage of sensori-motor intelligence (approx. 0-2 years). During this stage, behavior is primarily motor. Children do not yet think conceptually.

The stage of preoperational thought (approx. 2-7 years). During this stage, children can think conceptually; however, they have only onedimensional perception of reality. They are rigid and irreversible in their thinking. Their thoughts operate on the basis of their perception. 
Reasoning during this stage is prelogical. They often cannot support their statements with logical arguments.

The stage of concrete operational thought (approx. 7-11 years). During this stage, children can apply logical thought to concrete problems. Even though they have the ability to construct relationships among the objects which they observe, they cannot think of all possible actual or hypothetical relationships. They can see the relationship between the parts and the whole. They can also reflect and reverse their thoughts.

The stage of formal operational thought (approx. 11-adult). During this stage, "hypothetico-deductive" thinking appears. Children can internalize their own thinking and are able to think at an abstract level (Piaget, 1968).

The chronological ages during the stages of development are not fixed. One can expect to find different levels of development at the same chronological age (Piaget, 1968). However, all children pass through the stages of development in the same order. Children cannot jump from the preoperational stage to the formal operational stage without first going through the concrete operational stage (Piaget, 1968).

There are four factors which account for the rate of growth through the four stages of development: (a) maturation, (b) physical experience, (c) social interaction, and (d) equilibration. Piaget (1968) suggested that movement within and between stages of development is a function of these factors and their interaction.

While there are a number of factors that have been shown to affect problem-solving performance, only the factor of cognitive development was 
considered for this study. Research has shown that students' cognitive levels of development do affect their problem-solving performance. However, these studies only focused on translation problems. None of these studies included process problems.

\section{Statement of the Problem}

Research indicates that even when students are not enthusiastic about solving word problems, they tend to do well in one-step word problems (Carpenter et al., 1984). They do, however, have significant difficulty with process problems (Charles \& Silver, 1988; Lester, 1985; Schoenfeld, 1987; Silver, 1985). Solving process problems requires logical thinking (Charles \& Lester, 1985). According to Piaget (1970), logical thinking appears during the concrete operational stage. This leads to some questions for the study: Do third-grade children demonstrate a lack of ability to solve process problems? Are third-grade children logical thinkers? If children were not capable of solving process problems, then could it be attributable to their level of logical thinking? Furthermore, do children at the concrete operational stage perform better on process problems than do those children at the preoperational stage? The question which could be generalized from this would be: "What might be the relationship between children's achievement in process problems and their performance on Piagetian tasks designed to determine the level of children's cognitive development?"

\section{Statement of Purpose}

The purpose of this study was to examine the relationship that exists between the achievement of third-grade students in solving process 
problems taken from the third-grade Addison Wesley text, Problem Solving Experience for Mathematics (1984), and their cognitive levels of development as determined by Piagetian tasks.

Eight correlations were examined for this study.

1. Correlation between logical operations and process problems.

2. Correlation between number concepts and process problems.

3. Correlation between spatial concepts and process problems.

4. Correlation between conservation of length and process problems.

5. Correlation between conservation of weight and process problems.

6. Correlation between seriation and process problems.

7. Correlation between conservation of volume and process problems.

8. Correlation between the total scores of Piagetian tasks and the total scores of process problems.

\section{Operational Definitions}

1. Accommodation is the modification or adaptation of an individual as a result of experience. Accommodation to a new situation leads to the differentiation of a previous structure and, thus, the emergence of new structures (Piaget, 1968).

2. Assimilation is the process of incorporating environmental data into internal structures (Piaget, 1968).

3. Equilibration is the mental balance between environmental reality and inner cognitive structures. This mental balance is continually changed by the process of assimilation of and adaption to new information (Piaget, 1968).

4. Operation is an action that can be internalized, i.e., carried out in thought (Piaget, 1970). 
5. Structure refers to the organization of thought which is fundamental and constitutes a necessary foundation to the construction of more advanced levels of thought (Piaget, 1968).

6. Conservation is the ability to understand that objects are "conserved" and remain constant despite changes in their appearance (Piaget, 1968).

7. Logico-mathematical knowledge is the knowledge that is gained indirectly from one's activity with objects by reflecting on such activity (Piaget, 1970).

8. Hypothetico-deductive thinking refers to inferential thinking, which follows a hypothesis through to all possible logical conclusions (Piaget, 1968).

\section{Limitations}

1. Intercoder scoring reliability not conducted in this study.

2. Because of the limited number of parental permissions available, the subjects were not picked randomly.

3. Only one class of students was used in this study. 


\section{Chapter II}

\section{REVIEW OF THE LITERATURE}

Problem solving has been one of the most widely discussed topics within the mathematics education community and also has become one of the major goals of elementary school mathematics (Lester, 1980; Silver, 1985; Charles \& Silver, 1988). Lester (1980) pointed out that the ultimate aim of learning mathematics at every level is to be able to solve problems. Polya (1981) described the importance of problem solving:

Solving problems is the specific achievement of intelligence, and intelligence is the specific gift of man. The ability to go around an obstacle, to undertake an indirect course where no direct course presents itself, raises the clever animal above the dull one, raises man far above the most clever animals, and men of talent above their fellow men. (p. 118)

Even though problem solving has been the goal of mathematics education for the last decade, evidence shows that students still perform poorly in problem solving. Research shows that students often do quite well in one-step word problems, but have significant difficulty with multistep and process problems (Carpenter, et al., 1984). Why are process problems especially difficult for students? Process problems cannot be solved by simply translating word problems into one or more number sentences; they often require using some strategies, such as, guessing and checking, drawing a picture, making an organized list, making a table, or looking for a pattern (Charles \& Lester, 1984). Process problems emphasize logical thinking for obtaining problem solutions (Charles \& Lester, 1985). 
Siegler (1989) stated that children could not solve certain problems even when instruction was provided because they are lacking certain learning processes. The study of Riley, Greeno, and Heller (1983) concluded that the differences in performance on word problems are due to the knowledge which children have available to them at different ages. Cobb, Yackel, and Wood (1988) suggested that instructional activities should be designed so that "they make sense to, and can be solved by, children at qualitatively different conceptual levels" (pp. 111-112). The purpose of this study was to examine the relationship that exists between third-grade students' achievement in solving process problems and their cognitive levels of development.

The review of literature is divided into three sections. The first section distinguishes two types of word problems, translation problems and process problems. The second section discusses some factors that affect students' problem-solving performance. The final section discusses Piaget's theory of cognitive development.

\section{Translation Problems Versus Process Problems}

According to Charles and Lester (1985), word problems generally can be grouped into two categories: translation problems and process problems. The solution of translation problems often involves translating words into number sentences. Simple translation problems need only one operation for the solution, and complex translation problems need more than one operation. The following is an example of a complex translation problem: 
Carrie is allowed to watch television for 30 hours each week. If she watches for 15 hours on the weekend, how many hours, on the average, can she watch television on each weekday? (Charles et al., 1982, p. 74)

The solution of this problem involves two operations. First, students have to find the remaining television hours for the weekdays by using subtraction. Then, students can use division to find the average television hours for the weekday. This kind of problem, which involves applying operations, is most commonly found in a mathematics textbook. It requires routine application of an established procedure (NCTM, 1968). As long as students understand the problem and can master computation skills, they can solve a translation problem, usually within five minutes. Even though complex translation problems are more complicated to solve than the simple translation problems, the steps and the strategies for reaching the solution are still very predictable. Through drill and practice, solving this kind of problem often involves simple recall for many students (NCTM, 1968).

On the other hand, process problems cannot be solved solely by using an algorithm (Charles et al., 1982). According to Charles et al. (1982), "the solution of a process problem requires such strategies and skills as organizing information, guessing and checking, drawing pictures, or looking for patterns" (p. 74). The route to the solution of process problems is often not readily apparent and there is more than one route to the solution. For example: 
Some children are seated at a large round table. They pass around a box of candy containing 25 pieces. Ted takes the first piece. Each child takes one piece of candy as the box is passed around. Ted also gets the last piece of candy, and he may have more than the first and last pieces. How many children could be seated around the table? (Charles et al., 1982, p. 74)

This problem is not one where students can immediately write down a mathematical sentence and then solve it. Rather, students have to (a) understand the problem, (b) develop and carry out a solution strategy, and (c) evaluate the solution (Charles et al., 1982). In order to solve the candy problem, students have to first understand what question is being asked. They need to know that there is more than one answer for this problem. Unlike process problems, there are key words that trigger a standard procedures in translation problems (Davis et al., 1990). Once students understand the question, they can select an appropriate strategy for solving the problems. For example, the solution of this problem could involve drawing a picture and looking for a pattern. The process often requires several trials and errors. During the process of developing a strategy, students often engage in different kinds of problem-solving behaviors, such as formulating, generalizing, guessing, and organizing (NCTM, 1968). When students reach a solution for the problem, they have to use logical reasoning to check if the answer makes sense.

As one can see, process problems place more emphasis on the thinking process than do the translation problems. Students are required to engage in careful planning and thinking in the process of solving process problems. Unlike translation problems, there is no readily apparent algorithm for reaching the solution to process problems (Lester, 1980). 
Further, process problems do not focus on mastering computation skills; rather, they emphasize logical thinking (Charles et al., 1982).

Factors Affecting Problem-Solving Performance

The Role of the Teacher

In their 1989 study, Peterson et al. examined the relationship of teachers' knowledge of their students' problem-solving ability and the problem-solving performance of their students. The study involved 20 first-grade teachers participating in a 4-week workshop in which the teachers were given the findings of research on the development of children's mathematics learning. Throughout the school year, the teachers and students were observed during mathematics period. At the end of the school year, teachers were interviewed about their understanding of their students' knowledge and performance and students' completed achievement tests.

The results of the study by Peterson et al. (1989) indicated that teachers' knowledge of their students' problem-solving abilities was positively correlated with their students' problem-solving achievement. They also found that teachers' knowledge of their students' problemsolving abilities was positively correlated with the following teacher behaviors: questioning process, focusing on answers, and listening to answers. In contrast, teachers' knowledge of their students' problemsolving abilities was significantly negatively correlated with the following teacher behavior: explaining process.

Peterson et al. (1989) concluded that teachers with more knowledge of their students' problem-solving abilities tend to plan their instruction based 
on students' knowledge and attempt to connect procedural knowledge to students' conceptual understanding. Thus, their students' problem-solving performance was significantly higher than other groups. Also, students who were taught by more knowledgeable teachers, whereby procedural and conceptual knowledge were addressed, were more likely to solve advanced word problems because these students were able to use and to apply this knowledge to new problems. On the other hand, students who were taught by less knowledgeable teachers received only procedural knowledge. Even though they obtained average scores on one-step word problems, those students lacked the conceptual knowledge to attack new problems. Affect

Polya (1981) pointed out the importance of affect in the process of problem solving: "An essential ingredient of the problem is the desire, the will and the resolution to solve it" (p. 63).

According to McLeod (1985), two affective dimensions influence students' problem-solving performance. The first is the tension and relaxation in the problem-solving process. He found that too much tension often leads to mental blocks in the students' thinking. On the other hand, if students do not develop any tension when they encounter the problem, either they are not interested in the problem or the problem is too easy for them. He further pointed out that moderate tension seems to improve students' problem-solving performance. The release from tension that follows the solution of the problem provides the reward and satisfaction.

"Locus of control" is another affective factor influencing students' performance in problem solving (McLeod, 1985). If students attribute their 
failure to an internal factor, such as ability, or attribute their success to an external factor, such as luck or help from others, they often disbelieve their own ability to solve problems. For example, if students attribute their failures in problem solving to their lack of ability, they are likely to give up when they cannot solve the problem within 10 minutes. Also, if students attribute their success in problem solving to having help from the teacher, they often do not think they can solve the problem alone.

According to Piaget (1968), there is never a purely cognitive action, nor a purely affective action, in the process of problem solving. When children encounter conflicts in their experiences, the affective action provides the motivation for them to restructure their knowledge (Wadsworth, 1989). Pulaski (1971), in interpreting Piaget, stated: "Every intelligent act is accompanied by feeling and that these feelings provide the motivation, the energy that sparks intellectual growth" (p. 135). It is realized that no task can be divorced completely from affective influence. Cognitive Development

Student level of cognitive development constitutes another factor which can influence students' problem-solving performance in translation problems. According to Lester (1980), teachers need to be aware of these developmental changes, such as when students acquired and what processes students acquired, in order to maximize instructional effectiveness in the problem-solving program.

Nesher, Greeno, and Riley (1982) proposed a semantic analysis on word problems to suggest a hypothesis of developmental levels that can account for children's performances of these problems at various ages. 
They divided this study into three sections. In the first section, they suggested different categories of addition and substraction word problems.

The second section proposed developmental levels of word problem-solving ability, and the final section discussed how these developmental levels account for children's performance on arithmetic word problems.

There were 14 types of addition and subtraction word problems (Nesher et al., 1982):

Title

Combine 1

Combine 2

Change 1

Change 2

Change 3

Change 4

Change 5

Change 6

Compare 1

Compare 2

Compare 3

Compare 4

Compare 5

Compare 6

\section{General Description}

Questions about the union set (whole)

Questions about the union set (part)

Increasing, questions about the final set

Decreasing, questions about the final set

Increasing, questions about the change

Decreasing, questions about the change

Increasing, questions about the initial set

Decreasing, questions about the initial set

'More,' questions about the difference set

'Less,' questions about the difference set

'More,' questions about the 'compared'

'Less,' questions about the 'compared'

'More,' questions about the referent

'Less,' questions about the referent

(p. 376)

According to Nesher et al. (1982), there are four developmental levels of word problem-solving ability: (a) Level 1, Counting Sets. Children at this level have the ability to count and find the cardinal number of a given set; (b) Level 2, Change. Children understand the sequences of events ordered in time in a unidirectional and nonreversible manner. At this level, the "+" and "--" operations are distinct, not related; (c) Level 3, Part- 
Part-Whole. Children at this level understand the inverse relationship of the "+" and "-" operations. Also, the understanding of class inclusion is available at this level; (d) Level 4, Directional Relations. Children at this level have the ability to handle inequality, and the ability to equalize inequality by addition or subtraction.

At Level 1, children have some schemes available to solve Change 1 and 2 and Combine 1 problems. These problems can be solved on the basis of partial and local information. Children only need to count the sets in the problems. For example: "Joe has 3 marbles. Tom has 5 marbles. How many marbles do Joe and Tom have altogether?" (Nesher, et al., 1982, p. 385). At Level 2, children have some schemes available to solve Change 3 and 4 problems. Children are able to relate the change that occurred in the initial set and to estimate the direction of the change (increase or decrease). For example: "Joe had 3 marbles. Tom gave him some more marbles. Now Joe has 8 marbles. How many marbles did Tom give to Joe?" (p. 386). At Level 3, children can solve most addition and subtraction word problems except Compare 5 and 6 problems. They can understand the sets' relationships and distinguish the subsets. They know that if $a+b=c$, then $c-b=a$ or $c-a=b$. For example: "Joe has 3 marbles. Tom has 5 more marbles than Joe. How many marbles does Tom have?" (p. 389). At Level 4, children are flexible enough to invert the directional order relation to solve Compare 5 and 6 problems. They can handle inequality and the relationship to equality: If $a>b$, then $a-c=b$, or $\mathrm{b}+\mathrm{c}=\mathrm{a}$. For example: "Joe has 8 marbles. He has 5 more than Dan. How many marbles does Dan have?" (p. 391). 
Nesher et al. (1982) concluded that this analysis suggests the prerequisite knowledge for solving certain word problems and explains why certain problems are more difficult for children at different levels of performance. Thus, teachers can now be more sensitive to the sequence of instruction when they teach word problems.

Bana and Nelson (1978) conducted a study that aimed at testing the effects of distractors in nonverbal mathematical problems. They selected four matched groups, each consisting of 4 boys and 4 girls of Grades 1-3. The nonverbal problem used for the study involved partitive division. Each of the four groups at each grade level was randomly assigned to the problem in one of the four settings: minimal distraction, situational distraction, color-attribute distraction, and spatial-numerical distraction. The subjects were asked to solve the following problem: "We want to load all these cars (twelve) onto the three trucks. Every truck must take the same number of cars. How many cars will be on each truck?" When the subject gave the solution, the experimenter questioned the solution until the subject was committed to the solution. Further, the subjects were questioned as to the process used to arrive at the solution to see if the subjects were distracted.

Bana and Nelson (1978) found that manipulative solvers are more likely to be distracted than verbal solvers. For all three grades considered together, the group in the first problem setting with minimal distraction scored significantly higher than the group in the fourth setting with spatialnumerical distraction. They concluded that distractors do affect the problem-solving behaviors of young children. 
Piaget's Theory of Cognitive Development

According to Piaget (1968), knowledge is not given but, rather, is constructed by individuals for themselves. He suggested that knowledge is acquired through the resolution of conflict. The conflict which leads to cognitive reorganization is the result of assimilation and accommodation derived from action. He further proposed that children need to reach a certain level of cognition before they will be able to conceptualize ideas. Piaget (1964) stated that:

To receive information, a child must have a structure which enables him to assimilate this information. This is why you cannot teach higher mathematics to a 5-year-old. They do not yet have structures which enable them to understand. (p. 180)

Piaget stated that "human action consists of a continuous and perceptual mechanism of readjustment or equilibration" (p. 7). He suggested that cognitive development is a continual mental process of organization and reorganization. This process occurs in a succession of stages (Piaget, 1968). These stages are known as the sensori-motor, preoperational, concrete operational, and formal operational. Since thirdgrade students are most likely to fall between preoperational and concrete operational thought, the discussion focuses on these stages of development, with emphasis on the concrete operational stage.

\section{Levels of Development}

With the appearance of language and symbolic thought, children begin to enter the preoperational stage. They are able to reconstruct the past and anticipate future actions through verbal representation (Piaget, 1968). During this time, children's perceptual, conceptual, and logical thinking 
abilities are developing. They are, however, one-dimensional in their thinking at the preoperational period of time. As Piaget (1970) explained: "We have here operations that are lacking in reversibility; they work in only one direction" (p. 50).

At the preoperational stage, children concentrate on the static state of situations. The situations were explained more in terms of the characteristics of configuration at a given moment than in terms of changes from one state to another. For example, in one study, after watching two cartons of milk being poured into two glasses, one tall and thin, the other short and wide, children at the preoperational stage thought that one glass contained more milk than the other (Lowery et al., 1986). They centered on one dimension, such as length (or width), to make their decision and were then unable to reverse it.

Lowery et al. (1986) pointed out that preoperational children also "tend to focus on the end result rather than on the act of a transformation that neither adds to nor subtracts from any substance. Their responses reflect their inability to mentally return the material to its original state" (p. 67). For example, a clay ball is shown to a child, and then it is stretched out to form a sausage before the child's eyes. The preoperational child generally claims that the clay sausage is "more" than the clay ball because the clay sausage is longer than the ciay ball.

By the end of the preoperational stage, children begin to achieve the ability to reverse or decenter and are able to focus on transformations rather than on the static states (Piaget, 1968). Children are able to think logically in a concrete manner and become capable of reflection (Ginsburg 
\& Opper, 1979). However, children are able to think logically only in terms of the world of actual experiences, real objects, or events that have been in their experiences (Neufeld, 1976). Piaget stated: "While the child clearly evolves logical operations, these operations are only useful in solving problems involving concrete objects and events in the immediate present" (cited in Wadsworth, 1989, p. 96).

There are two key structures at the level of concrete operations: seriation and classification. According to Ginsburg and Opper (1979), "seriation is the ability to mentally arrange a set of elements accurately according to increasing or decreasing size, weight, or volume," and "classification is the ability to mentally group objects according to similarities" (pp. 119-123). These are the foundation of children's understanding of numbers (Gallagher \& Reid, 1981).

Another important characteristic of the concrete operational stage is reversibility. Lovell (1964) pointed out that "the fundamental skill that underlies all mathematical and logical thinking is the capacity for 'reversibility'" (p. 18). Reversibility frees children from being dominated by how things look (Piaget, 1968). In Genetic Epistemology, Piaget (1970) discussed two types of reversibility. The first one is reversibility by negation, for example, $+1-1=0$. The second one is reversibility by reciprocity. That was simply a reversal of order. For example, in $A=B$, the reciprocal was also true: $B=A$.

In the example of the two glasses of milk, concrete operational children will say that the amount of milk is "the same." They realize that height and width compensate for one another; they can mentally "pour" the 
milk from one glass to another. In the example of the clay ball, concrete operational children will also affirm that the sausage shape is the same as the clay ball, because the clay just changed its shape without adding or subtracting any clay. They also understand that an increase in length must be counterbalanced by a loss in width.

When children have the ability to perform mental operations, not only on concrete objects, but also on symbols, they are entering into the formal operational stage. Piaget (1968) stated that "formal operations provide thinking with an entirely new ability that detaches and liberates thinking from concrete reality and permits it to build its own reflections and theories" (p. 63). Children at this level can isolate variables in the problem and systematically test hypotheses rather than list all possible combinations (Gallagher \& Reid, 1981).

Factors Affecting Cognitive Development

According to Piaget, development is continuous and consistent. Each stage evolves out of the one before it and contributes to the ensuing one. However, there are four factors and their interaction which are necessary for development: maturation, physical experiences, social experiences, and equilibration. These factors help children move from one stage to another.

Physical maturation is dependent on heredity and is a spontaneous process of development (Gallagher \& Reid, 1981). According to Flavell (1971), "maturation indicated whether or not the construction of specific structures is possible at a specific age" (p. 193). However, the rate of maturation is influenced by environmental factors, such as physical and social experiences. 
Physical experience involves the interactions of children with their environment and provokes assimilation and accommodation to lead to cognitive changes (Wadsworth, 1984).

According to Gallagher and Reid (1981), social experience is "gained by interaction with people and included social relationships, education, language, and culture" (p. 45). Wadsworth (1989) noted that interaction with others can provoke disequilibrium relative to physical and logical mathematical knowledge.

Equilibration is also the regulator that coordinates existing knowledge with the new knowledge (Wadsworth, 1984). Piaget viewed this as a selfregulatory process. He also stated that equilibration is the fundamental factor in the acquisition of logical mathematical knowledge (Piaget, 1964).

Summary

The research question for this thesis was, "Is there a significant relationship between students' achievement in solving process problems and their cognitive levels of development?" Although many factors can be attributed to students' problem-solving performance, this study focused on the factor of cognitive development. Research that has been carried out thus far involved the relationship between cognitive development and problem-solving ability and has been limited to translation problems. This study focused on process problems which require logical thinking. 


\section{Chapter III}

\section{METHODOLOGY}

The purpose of this study was to examine the relationship between the achievement of third-grade students in solving process problems and their cognitive levels of development.

\section{Subjects}

The sample population was drawn from third-grade students in the Evergreen School District. The district is located in the Evergreen Valley of San Jose, California and serves an ethnically diverse population of low to upper-middle income households. The sample for this study consisted of 20 students: 10 boys and 10 girls drawn from a 30-student third-grade classroom. These particular students were chosen on the basis of parental permission and because they attended a third-grade class whose teacher was interested in the proposal contained in this study.

There were two reasons for choosing third-grade students as the subjects for this study. First, solving process problems requires logical reasoning, which is the characteristic of concrete operational children; most third-grade students would be expected to be at the concrete operational level (Piaget, 1968). Second, the subjects ranged from 7 to 9 years of age. According to Piaget (1968), one can expect to find different levels of development at the same chronological age. Some subjects could still be at the preoperational level, and some may have just entered into the formal operational level. Third grade, therefore, 
seemed to be the optimum time to observe the process problem solving in relationship to the level of cognitive development.

Tools and Instruments

Seven Piagetian tasks were selected from Piagetian Tests for the Primary School by Fogelman (1970), The Philosophy of Jean Piaget and Its Educational Implication by Neufeld (1976), The Six Psychological Studies by Piaget (1968), and It's the Thought That Counts, by Lowery et al. (1986). The seven tasks measure the abilities of number sense, logical operations, spatial concepts, seriation, conservation of weight, volume, and length. Here are descriptions of the seven tasks:

1. Number Sense:

Materials: Two piles of cubes, one containing 8, the other 14 .

Procedure: Children were asked to do the following: "Move some cubes from the big pile into the little one to give two children just the same amount of cubes to play with."

2. Logical Operations:

Materials: Four blue squares, four blue triangles, three red triangles.

Procedure: Children were asked the following questions:

(a) "Are there more blues or squares?"

(b) "Are there more reds or triangles?"

(c) "Are there more triangles or blues?"

3. Spatial Concepts:

Materials: An outline of a steep hill on a white sheet of paper. 
Procedure: The children were asked to draw two houses and two telephone poles on the hill.

4. Seriation:

Procedure: Subject was asked the following question: "Edith has darker hair than Lily. Edith's hair is lighter than Susan's. Which of the three has the darkest hair?"

5. Conservation of Weight:

Materials: A lump of clay and a balance scale.

Procedure: The researcher placed a lump of clay on a balance scale. Then the researcher said: "Make a lump of clay that you think will weigh the same as this one." Then, the researcher changed the shape of one lump, made it flatter and longer. Before putting the changed lump back on the scale, the researcher asked the subject, "Now, which lump of clay will weigh more, or will they both weigh the same?" Subject was asked to explain the answer.

6. Conservation of Volume:

Materials: 36 cubes, 1 mat (with figures of one 3 by 4 shape, one 3 by 3 shape, and one 1 by 4 shape on the mat), 1 box (with the dimensions of 3 by 3 by 4 so that 36 cubes are arranged in a 3 by 3 by 4 pattern, which make up the same volume).

Procedure: Indicating the box that is resting on the 3 by 4 shape on the mat, tell the subject the following story: "People lived in this building at one time, but a big wave washed it all away. All of the families were saved, but they now must settle on another 
island. If they settled on this one (pointing to the 3 by 3 shape), how many stories high would their building have to be?" Then, while pointing to the 1 by 4 shape, ask, "What if they decided to settle on this one?" Allow the subject ample time to attempt to solve the problem. The 36 cubes should be available for the subject so that he or she can actually construct the "building."

7. Conservation of Length:

Materials: Two equal-length pencils.

Procedure: The pencils were placed with their extremities coinciding so that the child agreed that they were equal: (a) One pencil was pushed slightly ahead of the other; (b) the pencils were placed to form the letter " $\mathrm{T}$ "; (c) the pencils were touching at an acute angle. Each time the child was asked which pencil was longer.

Tasks 1, 2, 3, 5, and 7 were concrete operational tasks. The subject scored 3 if the response was correct with the explanation; 2 if the response was correct, yet there was no explanation; and 1 if the response was incorrect. Tasks 4 and 6 were formal operational tasks. The subject scored 5 if the response was correct with the explanation; 4 if the response was correct with some explanation; 3 if the response was correct with no explanation; 2 if the response was not completely correct; and 1 if the subject had no idea about the task.

A total of 12 process problems (see Appendix B) was selected from the third-grade edition of Addison Wesley Problem-Solving Experiences in Mathematics (1984). As process problems cannot be solved by simply 
choosing one or more operations, they provide practice with the thinking processes inherent in problem solving. According to the organization of process problems in the book, the problems were categorized by what strategies could be used to solve the problems. So as to present various types of problems, some were drawn from each category. Three problems were drawn from each of these categories: (a) use logical reasoning and (b) look for a pattern; and two problems were drawn from these categories: (a) make a list, (b) draw a picture, and (c) guess and check.

Charles \& Lester's holistic assessment of performance (1984) was used to give a score for each process problem (see Appendix A).

Procedures for Collection of Data

Piagetian tasks were administered individually to each subject. The testing was conducted away from the classroom to avoid distractions. To insure uniformity in testing procedures, the researcher collected all the data. Subjects were required to respond to each task verbally. The task materials were placed in seven stations. When the subjects completed one task, they moved to the next task station. A score sheet was used to keep scores and record subjects' responses. It was explained to the subjects that this was not a test. Subjects were made to feel comfortable before administering the task and given plenty of time to respond to the questions.

A set of process problems was administered to the subjects during the regular school day. The 12 problems were divided and given in two different periods in one day. The subjects had 30 minutes to use paper and pencil to solve six process problems each period. It was explained to the subjects that the goal of solving these problems was neither speed nor 
competition with one another. They were told to take their time, read the problems carefully, try their best to solve the problems, and show all of the work. An effort was made to make the problem-solving environment as comfortable as possible. Subjects were allowed to raise their hands to ask questions about the problems. Ciarification and hints were provided if subjects had no idea about how to begin to solve them.

Data Analysis

The State Pac Gold program (1988) was used to find the Pearson product-moment correlation coefficients for all testing scores. The Pearson I was calculated to show the linear relationship between two variables (scores of Piagetian tasks and process problems). The Pearson $r$ for the Piagetian tasks and process problems were compared to look for any positive relationship between the level of development and the achievement in process problems. Results were analyzed to examine the following comparisons:

1. Correlation between number sense and process problems.

2. Correlation between logical operations and process problems.

3. Correlation between spatial concepts and process problems.

4. Correlation between seriation and process problems.

5. Correlation between conservation of weight and process problems.

6. Correlation between conservation of volume and process problems.

7. Correlation between conservation of length and process problems.

8. Correlation between the total scores of Piagetian tasks and process problems. 
Chapter IV

\section{ANALYSIS OF DATA}

\section{Introduction}

The purpose of this study was to determine if there was a positive relationship between the achievement in solving process problems of third-grade students and their cognitive levels of development. The subjects for this study were 20 third-grade students from a public elementary school. The data for this study consisted of Piagetian test scores and process problem scores from 18 subjects. Two subjects were eliminated from the data analysis because they were pulled out for a special reading program during the testing period.

Results

There were eight correlations performed, comparing performance on Piagetian tasks with achievement on process problems. Scores of both Piagetian tasks and process problems for 18 subjects are presented in scattergram form, to show a pictorial display of score patterns. Simple regression was used to draw the scattergrams. Due to overlapping scores on process problems, less than 18 data values could appear on some scattergrams. There is a detailed summary giving statistical data for each correlation in Appendix D. The same process problems were used for each correlation (see Appendix B).

Correlation \#1: Number sense and process problems:

In the number sense task, subjects were asked to arrange two unequal piles of cubes into two equal piles. The scores of number sense 
tasks ranged from 0 to 3 points (see Figure 1). Since total process problems which measured against each Piagetian task were the same, the scores of process problems all ranged from 1 to 60 points in each correlation. Out of 18 subjects, 17 received 3 points on the number sense task. The performances of subjects on this task were all similar. All but one subject successfully arranged two unequal piles of cubes into two equal piles. Subjects' performances on number sense and their achievement of process problems were independent from each other. The correlation coefficient for these two variables is -.0353 , indicating a very low negative correlation between number sense and process problems. Correlation \#2: Logical operations and process problems.

In the logical operations task, subjects were asked to answer some logical inclusion questions, such as, "Are there more blues or squares?" Figure 2 also shows that the scores of logical operations ranged from 1 to 3 points. Out of 18 subjects, 16 received 3 points on the logic task. The subjects were homogeneous with respect to the logical operations task. Most of them could answer the questions of logical inclusion correctly. Subjects' performances on the logic operations and their achievement of process problems were independent from each other. The correlation coefficient for these two variables is .1306 , indicating that there is a low positive correlation between logical operations and process problems. 


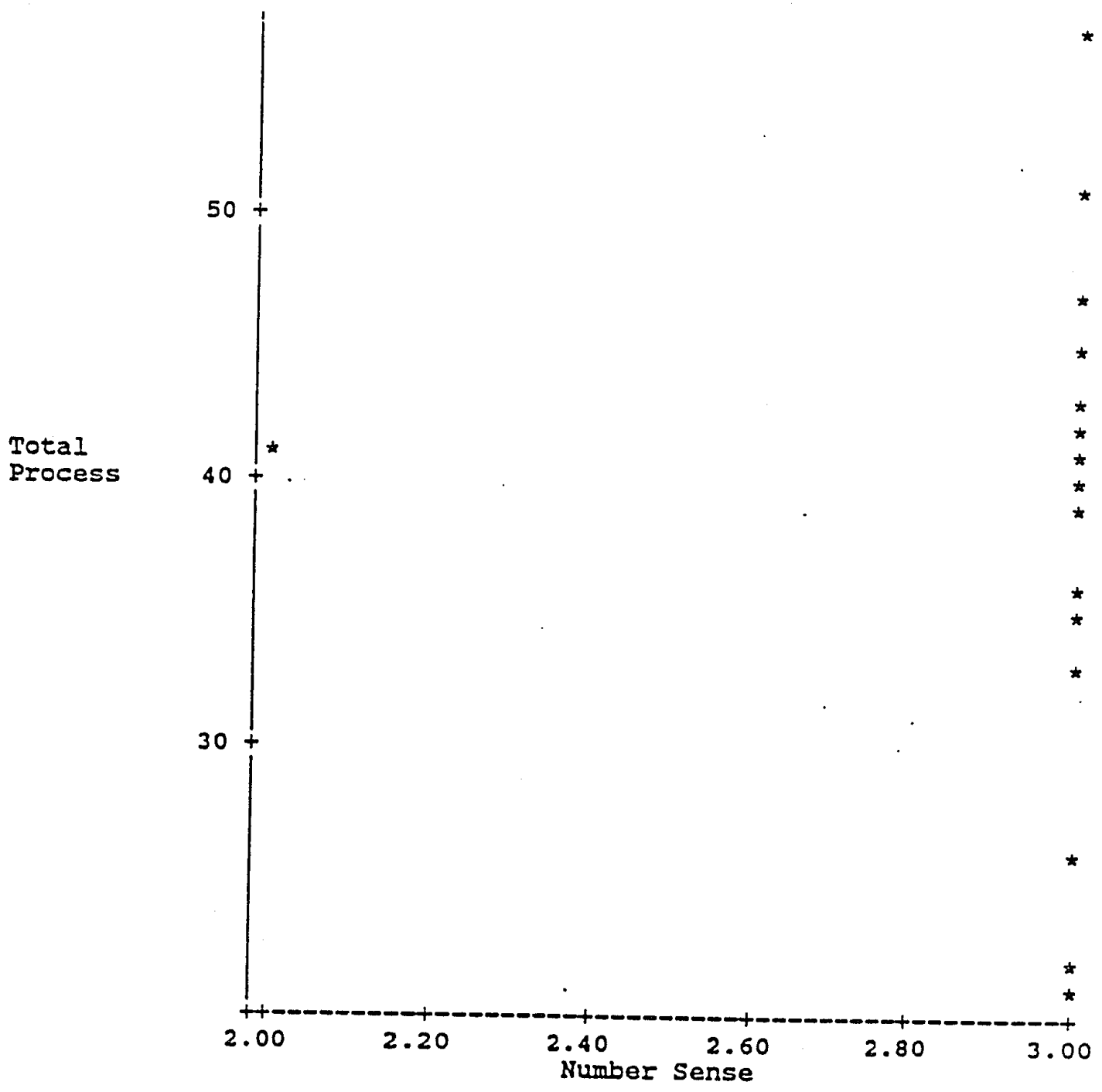

Figure 1. Number sense and process problems scores.

Correlation coefficient $=-.0353$

Level of significance $=.8894$ 


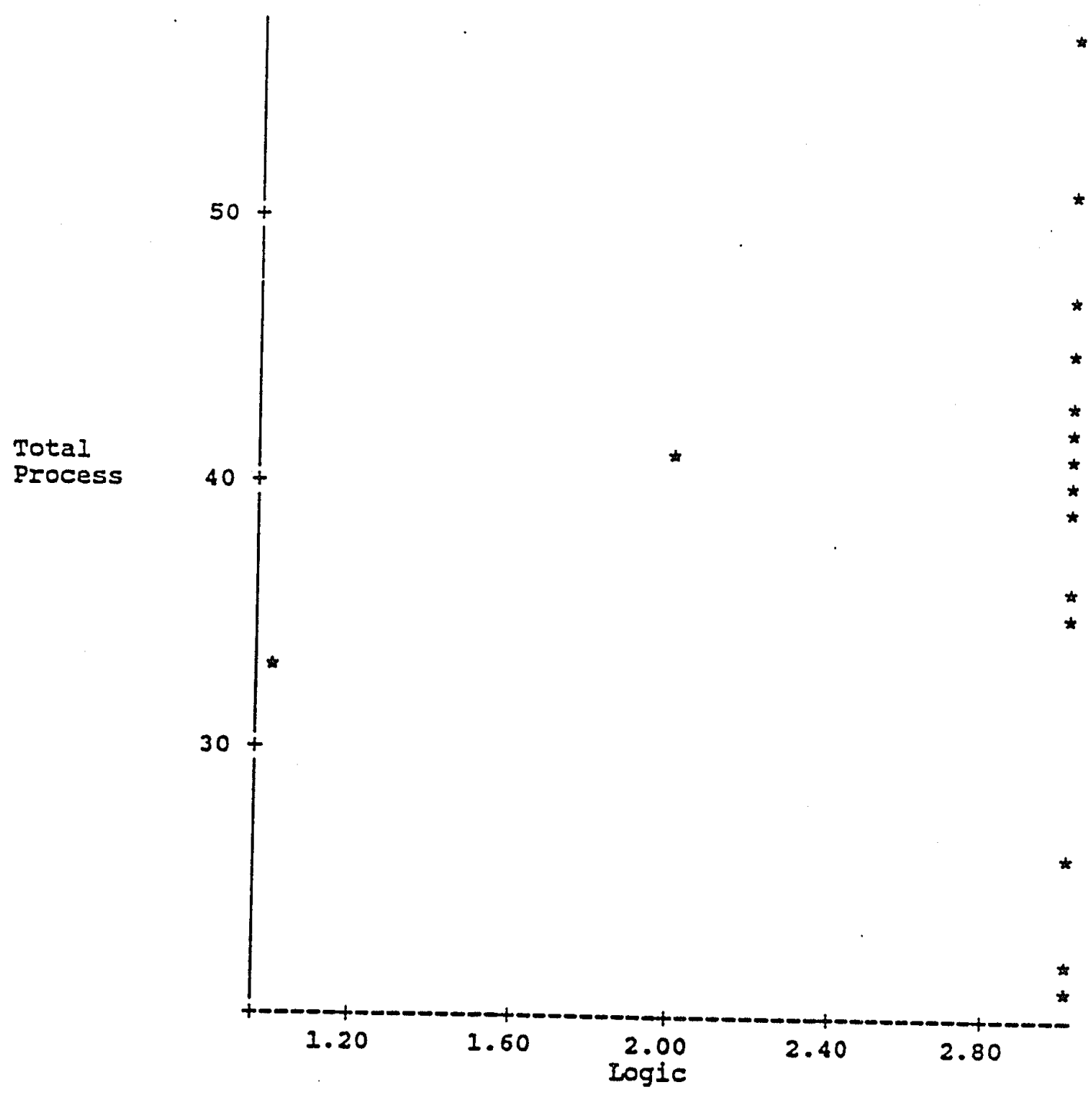

Figure 2. Logic operation and process problems scores.

Correlation coefficient $=.1306$

Level of significance $=.6054$ 
Correlation \#3: Spatial concepts and process problems.

In the spatial task, subjects were asked to draw houses and poles on the hillside. Figure 3 shows that scores of the spatial task ranged from 1 to 3 points. In this task, subjects who received low scores on spatial tasks had both high and low scores on process problems. Results indicate the ability of drawing the houses and poles correctly on the hillside had very little relationship to process problems performance. The correlation coefficient for these two variables is .0804 , with very low positive correlation between spatial concepts and process problems. Correlation \#4: Seriation and process problems.

This seriation task required the subjects to list three fictional people in logical order. Figure 4 shows that the scores of the seriation task ranged from 1 to 5 points. Figure 4 reveals that subjects who scored high on the seriation task had a slight tendency to achieve high scores on process problems and vice versa. The correlation coefficient for these two variables is .3942 , meaning that subjects' performance in the seriation task was positively, but not significantly, related to their achievement in process problems.

Correlation \#5: Conservation of weight and process problems.

In this task, subjects were asked to predict the weight of the clay after its shape was changed and give a justification for their predictions. Figure 5 shows scores of weight conservation ranging from 1 to 3 points. Subjects scoring high on the weight task could also achieve high scores on process problems and vice versa. The correlation coefficient for these 


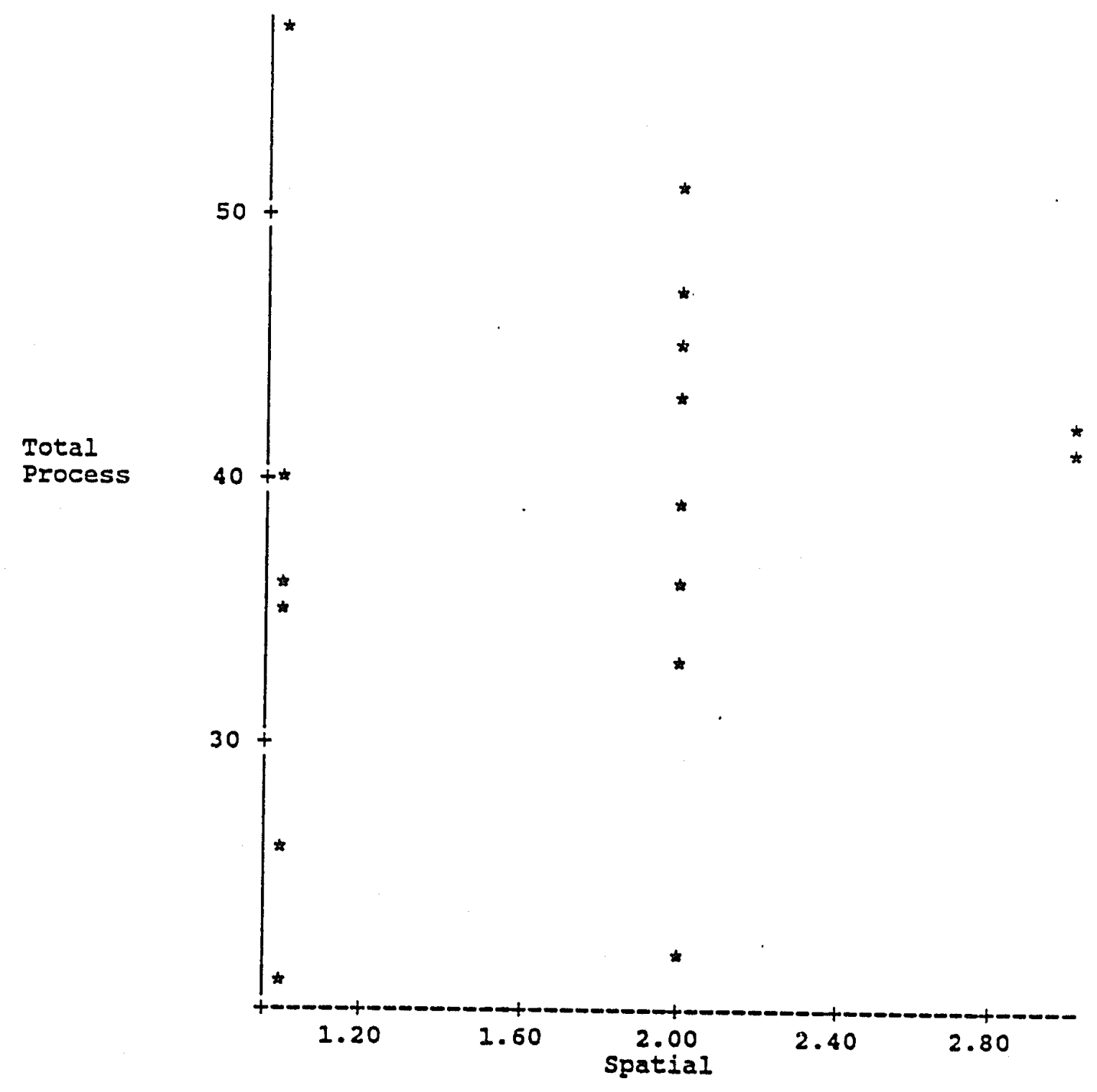

Figure 3. Spatial concepts and process problems scores.

Correlation coefficient $=.0804$

Level of significance $=.7510$ 


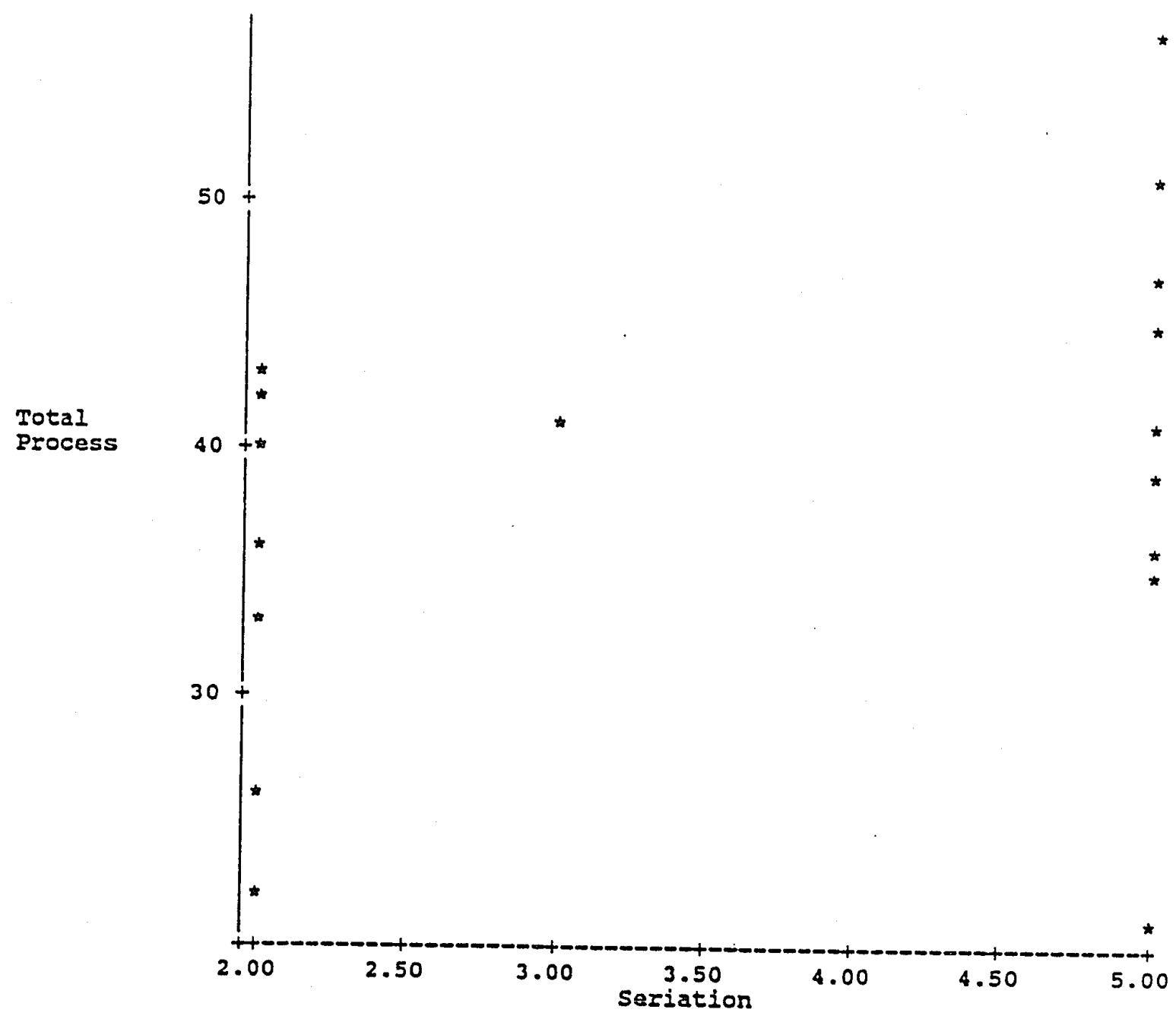

Figure 4. Seriation and process problems scores.

Correlation coefficient $=.3942$

Level of significance $=.1055$ 


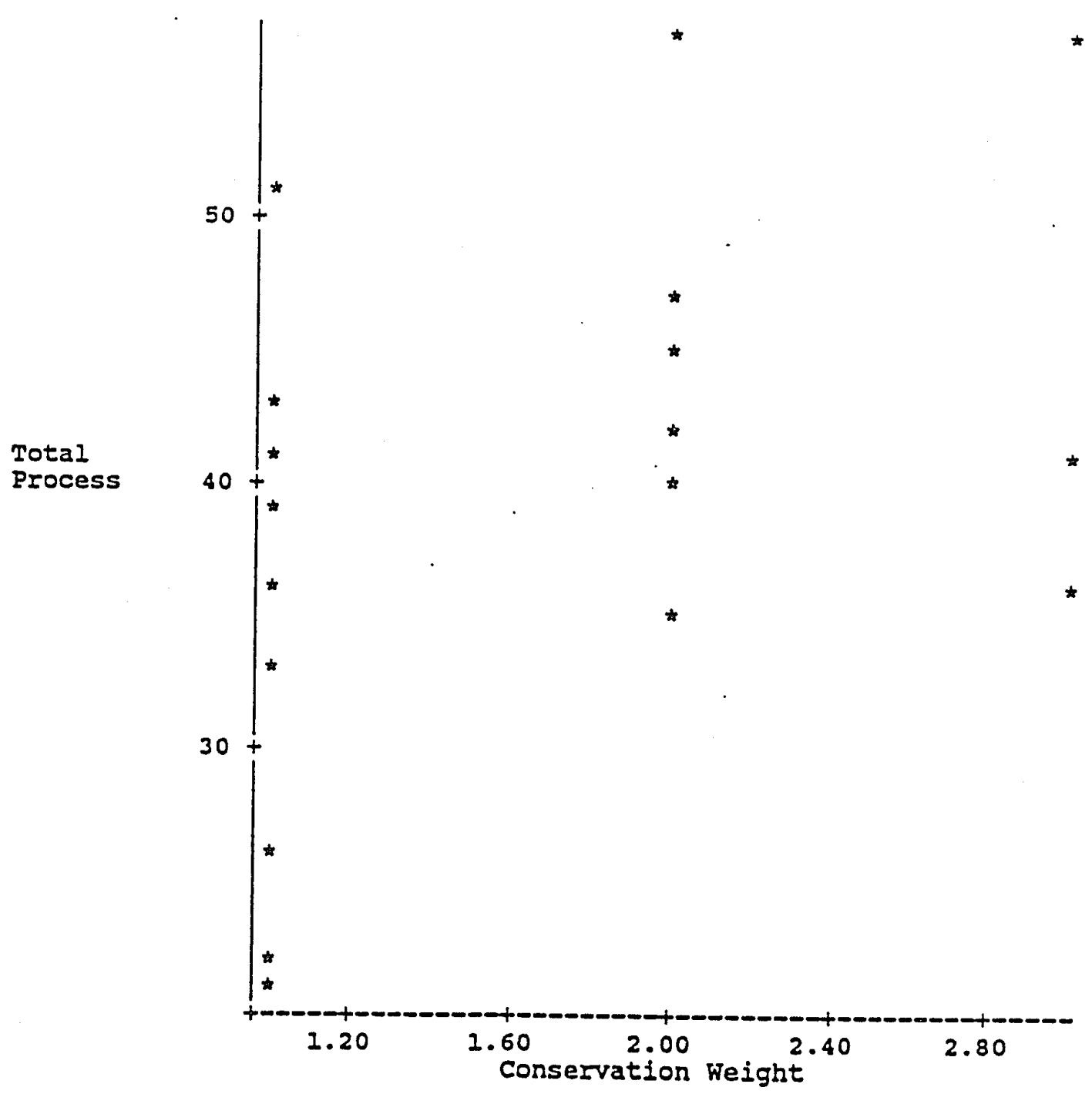

Figure 5. Conservation of weight and process problems scores.

Correlation coefficient $=.4457$

Level of significance $=.0638$ 
two variables is .4457 , indicating a positive, but not significant, relationship between conservation of weight and process problems. Correlation \#6: Conservation of volume and process problems.

This task required subjects to study the pattern of the original building on the 3 by 4 base and use logical thinking to determine how many stories the new building would have on the 3 by 3 base and on the 1 by 4 base to have the same number of rooms as the original building had contained. Due to limited time, subjects were asked only to answer how many stories the building would have on the 3 by 3 base. Figure 6 shows that scores of volume conservation ranged from 1 to 4 points. Subjects scoring high on conservation of volume tended to have high scores on process problems. This was the most difficult task among the seven for subjects to perform. The correlation coefficient for these two variables is .5139 . The correlation is at .05 level of significance, indicating a significant positive correlation between conservation of volume and process problems.

Correlation \#7: Conservation of length and process problems.

In this task, subjects were asked to determine whether the two pencils still had equal length after being moved around. Figure 7 shows scores of length conservation ranging from 1 to 3 points. Subjects who scored high on conservation of length tended to have high scores on process problems. The correlation coefficient of these two variables is .5957. The correlation is at .01 level of significance, indicating a significant positive correlation between conservation of length and process problems. 


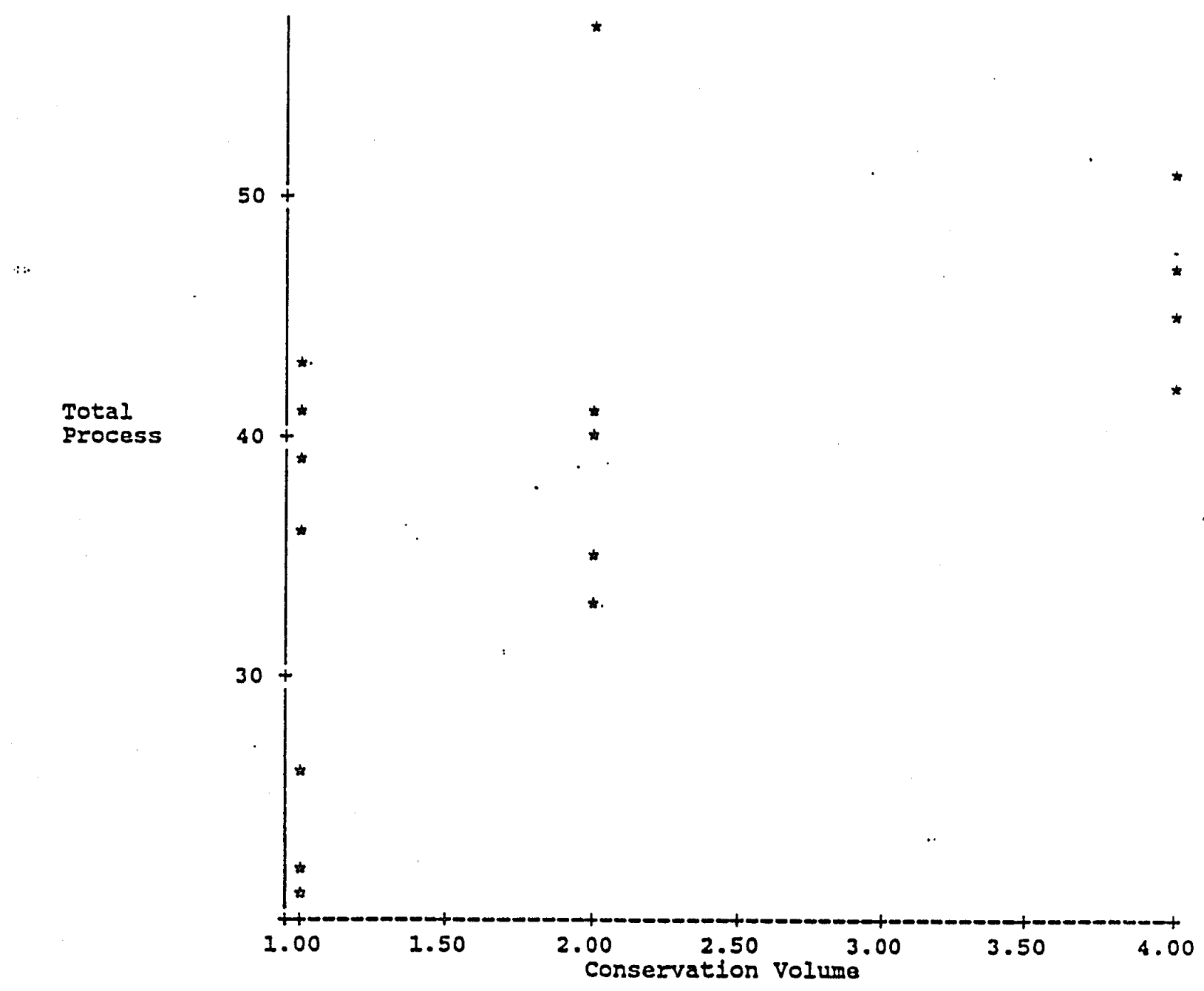

Figure 6. Conservation of volume and process problems scores.

Correlation coefficient $=.5139$

Level of significance $=.0291$ 


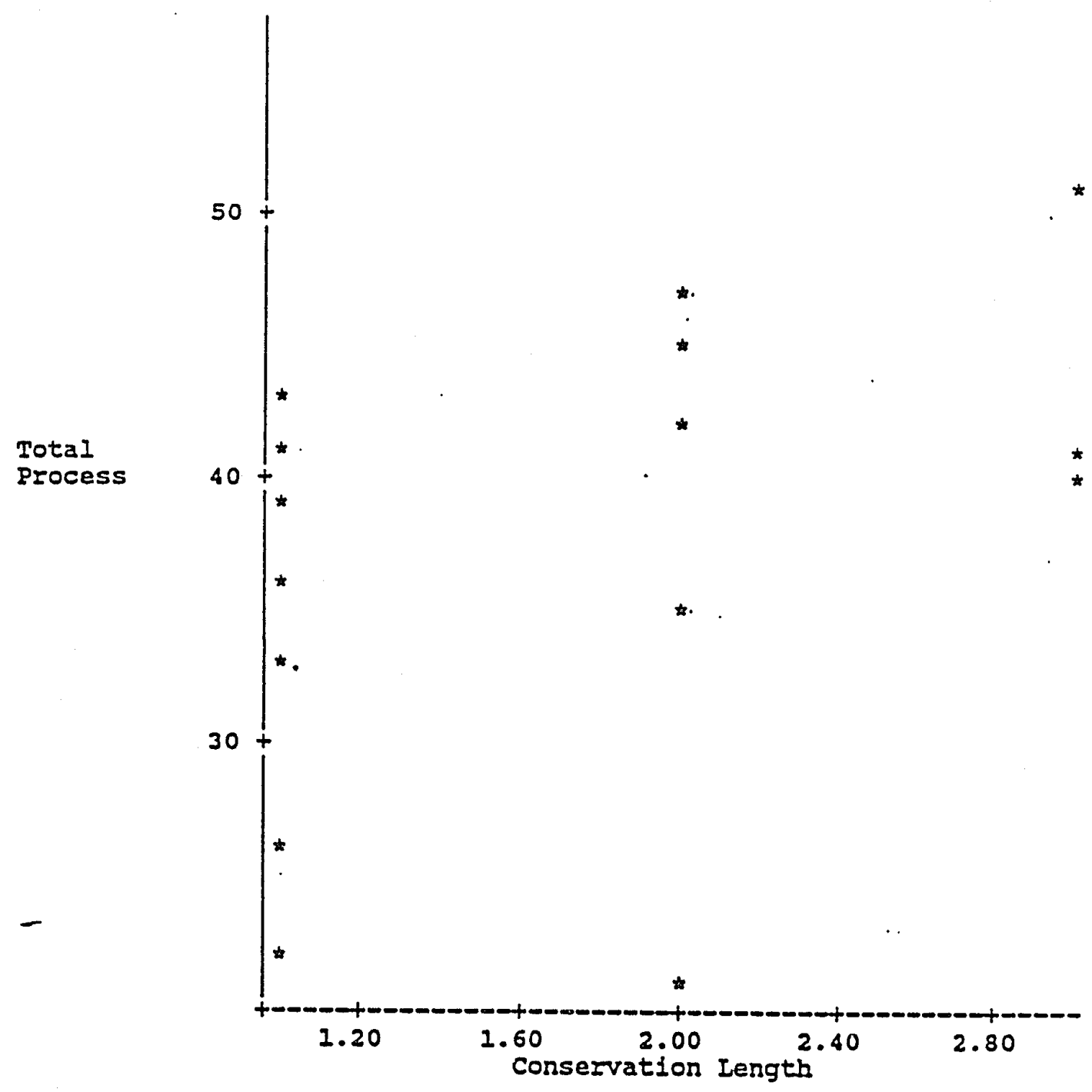

Figure 7. Conservation of length and process problems scores.

Correlation coefficient $=.5957$

Level of significance $=.0091$ 
Correlation \#8: Total Piagetian tasks and process problems.

The total Piagetian tasks scores were derived from total scores of previous seven Piagetian tasks to see subjects' overall performance in Piagetian tasks. Figure 8 shows total scores of Piagetian tasks ranging from 12 to 21 points. Subjects who achieved combined high scores on Piagetian tasks tended to have higher scores on process problems. The correlation coefficient of these two variables is .6498; the correlation is at the .01 level of significance, indicating subjects' overall performance on Piagetian tasks was significantly positively related to their achievement on process problems. Results also imply a positive correlation between students' achievement in process problems and their cognitive levels of development.

Summary of Results

Results of this study indicate that subjects' performance on number sense, logical operations, and spatial concepts had a low positive relationship to their achievement on process problems. Subjects' performance on seriation and conservation of weight was positively, but not significantly, related to their achievement on process problems. Subjects' performance on conservation of volume and conservation of length was significantly positively related to their achievement on process problems. The results of this study also indicate that the subjects' overall performance on the Piagetian tasks was significantly positively related to their achievement on process problems. Those subjects who scored high in the Piagetian tasks tended to have high scores in the process problems area as well. 


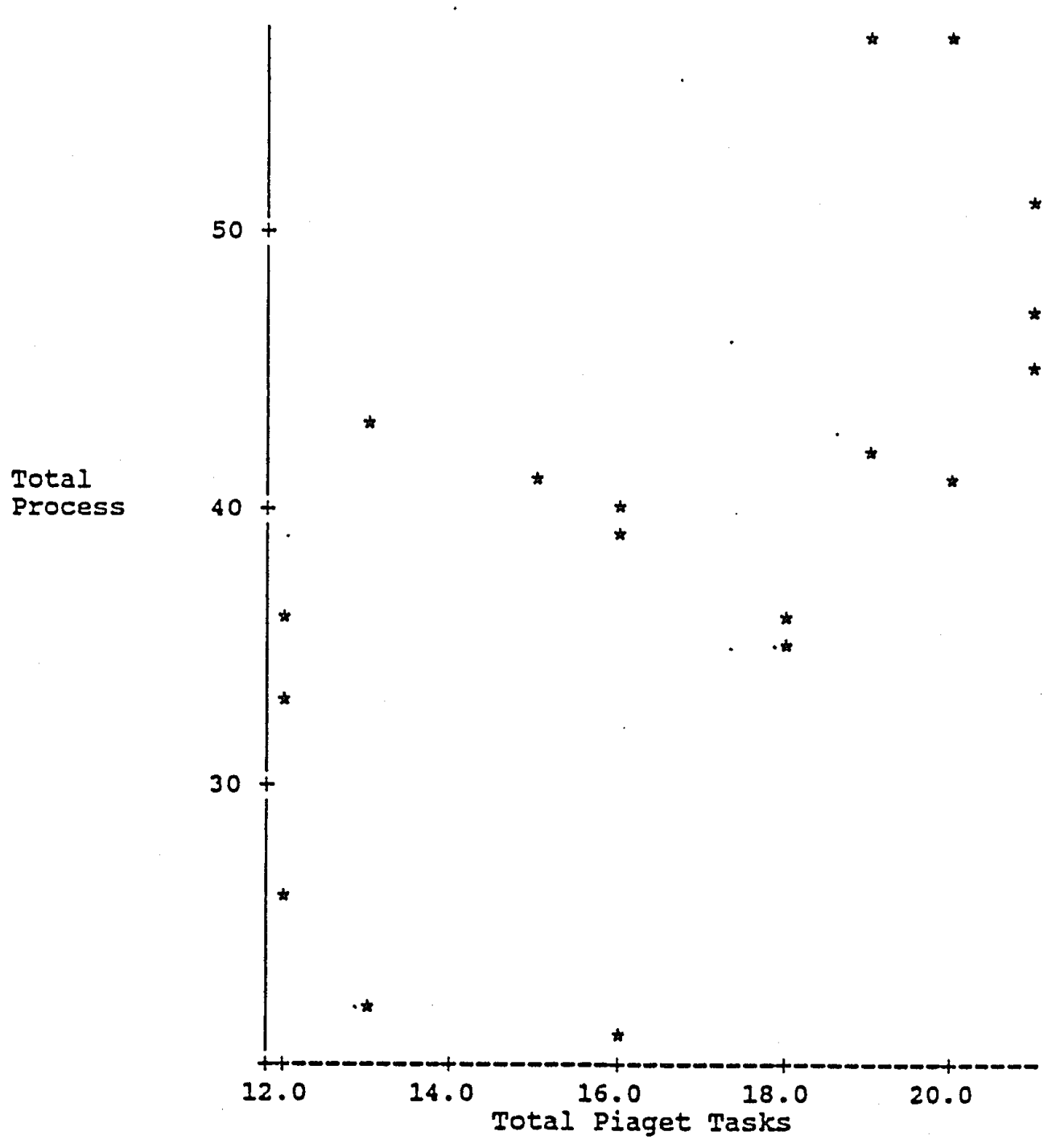

Figure 8. Total Piagetian tasks scores and process problems scores.

Correlation coefficient $=.6498$

Level of significance $=.0035$ 
Chapter V

\section{SUMMARY AND CONCLUSIONS}

The purpose of this study was to determine if a positive relationship could be found between the achievement of third-grade students in solving process problems and their cognitive levels of development.

For the last decade, problem solving has become the most important goal to be achieved in a K-12 mathematics program. The California Mathematics Framework (California State Department of Education, 1985) and the Curriculum and Evaluation Standards (NCTM, 1989) both stress that problem solving is one of the major themes in mathematics education reform. The essence of problem solving is to enable students to use their knowledge and experience when encountering new and unexpected situations (California State Department of Education, 1985). According to the Curriculum and Evaluation Standards (NCTM, 1989), "the development of each student's ability to solve problems is essential if he or she is to be a productive citizen" (p. 6). Even though problem solving has been the major concern in the mathematics education community since the 1970 's, word problems, especially process problems, which require logical thinking, are still difficult for most students.

According to Charles and Lester (1985), word problems can be generally grouped into two categories: translation problems and process problems. The solution of translation problems involves translating words into number sentences and using one or more operations. On the other hand, the solution of process problems involves more complicated 
strategies, such as, guessing and checking, drawing a picture, making an organized list or a table, looking for pattern (Charles \& Lester, 1985).

According to Curriculum and Evaluation Standards for School Mathematics (NCTM, 1989), problem-solving instruction should focus on helping students develop and apply strategies to solve problems. Since process problems emphasize thinking and applying strategies for the solution, process problems have been increasingly addressed in problemsolving instruction (NCTM, 1989). Furthermore, students often engage in different types of problem-solving behaviors in solving process problems. Therefore, process problems could be a useful tool to help students develop their problem-solving abilities.

Researchers have been trying to uncover reasons which might affect students' problem-solving performance. The role of the teacher in problem-solving instruction could directly affect students' performances. Lester (1980) pointed out that teachers' awareness of students' developmental change behaviors related to problem solving can affect their instructional effectiveness. The study of Peterson et al. (1989) also indicated that teachers' knowledge of their students' problem-solving ability is positively related to students' problem-solving achievement.

According to McLeod (1985), two affective factors can influence students' problem-solving performance. The first is the tension and relaxation in the problem-solving process. He found that moderate tension seems to improve students' problem-solving performance. "Locus of control" is another factor attributable to students' belief in their own ability in problem solving. Piaget (1968) also pointed out that in the 
process of problem solving, there is never a purely cognitive action, nor a purely affective action.

Cognitive level of development can be another factor influencing students' problem-solving performance. Nesher et al. (1982) used a semantic analysis on word problems to discuss how different developmental levels account for children's performance of word problems at various ages. In another study, Bana and Nelson (1978) found out that irrelevant data affect children's problem-solving performance, and spatial-numerical distractions appear to be the strongest. Even though both studies showed that students' cognitive level of development does affect their performance on word problems, they only focused on translation problems.

The cognitive theory of Piaget has provided important information about how children arrive at certain solutions to problems. The theory reflects the thinking of the child at different cognitive levels which provides educators with another view of children's problem-solving performance. Piaget identified different stages of cognitive development through which children pass. Children who are at the preoperational stage often operate their thoughts on the basis of their perceptions. They tend to center on one aspect of an event or an object. On the other hand, concrete operational children can apply logical thought to concrete problems. They are able to "decenter" and evaluate more than one aspect of an event or an object. However, not until the formal operational stage do children internalize their own thinking and are able to think at an abstract level (Piaget, 1968). The stages of cognitive development that 
children are in do affect their problem-solving performance. For instance, children at the preoperational stage would have great difficulty solving process problems which require logical thinking.

Even though the role of the teacher and affect were both equally important in their effect on students' performance in problem solving, this study has limited itself to but one factor--cognitive development--to see just how it affects students' achievement in process problems.

The present study was designed to investigate whether a significant relationship could be found between the achievement of 20 third-grade students in solving process problems and their cognitive levels of development. Seven Piagetian tasks were administered individually to measure the level of number sense, logical operations, spatial concepts, seriation, and conservation of weight, volume, and length. Subjects were tested on 12 process problems to determine their levels of achievement in problem solving. These 12 problems could be solved by using the following strategies: guessing and checking, drawing a picture, making a list, and looking for pattern.

\section{Results}

The results of this study showed that students' achievement on process problems had a very low correlation to the following Piagetian tasks: number sense, logical operations, and spatial concepts. Students' achievement on process problems were positively, but not significantly, related to their performance on the tasks of seriation and conservation of weight. Students' achievement on process problems were significantly positively related to their performance on conservation of volume and 
length. Overall, there was a significant positive relationship between the achievement of third-grade students in solving process problems and their cognitive levels of development which were determined by these seven Piagetian tasks. Certain behaviors which added to the value of the study were observed as the subjects engaged in solving process problems. Subject 4 and subject 9 were very engaged in the process of solving the problems and were the only two subjects who wrote detailed descriptions on how they solved each problem. Not surprisingly, they were also the two subjects who received the highest scores (57) on process problems (see Appendix C).

\section{Discussion}

Research has shown that children's cognitive development does affect their performance in word problems in general (Nesher et al., 1982). However, there was no research about the relationship between cognitive development and performance in process problems. This study was designed to investigate the relationship between the achievement of third-grade students in solving process problems and their cognitive levels of development.

During the testing of Piagetian tasks, it was obvious that most students were at the concrete operational level in the number sense and logical operations tasks. They could successfully complete these tasks with a logical explanation. In the spatial task, it seemed that the ability to draw the houses and poles correctly had an insignificant effect on the performance in process problems. As for the seriation task, it had been anticipated that this would be among the most difficult of the tasks for 
this group of students. Surprisingly, many of the students could answer this question correctly. The conservation of weight, volume, and length tasks were better tasks in terms of reflecting different levels of cognitive development for this group of students. The preoperational children tended to focus on one aspect of the task; conversely, the concrete operational children could look for more than one aspect of the task and provide a logical explanation for their answers.

One interesting behavior of the children was observed during the testing of process problems. Most of the students had very short attention spans on the problems. Whenever they encountered some difficulty with the problems, their first reaction was to ask for help without thinking it over, even though they were encouraged to try on their own. This behavior supported Schoenfeld's (1985) claim that children often give up on problems if they cannot find the solution within a short period of time.

The result of this study might increase the understanding of why process problems are more difficult for some third graders. With this knowledge, teachers can tailor their problem-solving program to accommodate students at different developmental levels. Although the implications of this study are significant, one must consider that there is relatively little literature currently available which addresses the issue of cognitive development in relation to process problems. Perhaps one of the most significant implications of this study is the need for further research into student performance in process problems and the relationship to cognitive development. 
Recommendations

Recommendations for future study are:

1. To conduct a study utilizing a larger group of students.

2. To administer process problems on two different days.

3. To administer Piagetian tasks and allow ample time for the subjects to complete each task. The time allotted to administering all seven tasks should be about 20 to 30 minutes.

4. To vary the order of the Piagetian tasks.

5. To interview subjects about how they solved each of the process problems is reconimended for the next phase of this study. This could be most instructive in understanding the logical thinking used in solving process problems. 


\section{REFERENCES}


References

Bana, J., \& Nelson, D. (1978). Distractors in nonverbal mathematical problems. Journal for Research in Mathematics Education, 9(1), 55-61.

California Assessment Program. (1980). Student achievement in California schools: 1979-80 annual report. Sacramento: California State Department of Education.

California State Department of Education. (1985). Mathematics Framework. Sacramento, CA: California State Department of Education.

Carpenter, T., Lindquist, M., Matthews, W., \& Silver, E. (1984). Achievement in mathematics: Results from the national assessment. The Elementary School Journal, 84(5), 485-495.

Charles, R. I., \& Lester, F. K. (1985). An evaluation of a processoriented instructional program in mathematical problem solving in grade 5 and grade 7. Journal for Research in Mathematics Education, $\underline{15}(1), 15-34$.

Charles, R. I., \& Lester, F. (1984). Problem-solving experiences in mathematics. Menlo Park, CA: Addison-Wesley Publishing.

Charles, R. I., Mason, R. P., \& White, C. A. (1982). In Mathematics for the middle grades (5-9), 1982 Yearbook of the National Council of Teachers of Mathematics, pp. 73-82. Reston, VA: The Council.

Charles, R. I., \& Silver, E. (Eds.). (1988). The teaching and assessing of mathematical problem solving. Reston, VA: Lawrence Eribaum.

Cobb, P., Yackel, E., \& Wood, T. (1988). Curriculum and teacher development as the coordination of psychological and anthropological perspectives. In E. Fennema, T. Carpenter, \& S. Lamon (Eds.), Integrating research on teaching and learning mathematics (pp. 92131). Madison: University of Wisconsin, Wisconsin Center for Educational Research. 
Davis, B. R., Maher, A. C., \& Noddings, N. (Eds.). (1990). Constructivist views on the teaching and learning of mathematics. Journal for Research in Mathematics Education Monographs (No. 4).

Flavell, J. (1971). The use of verbal behavior in assessing children's cognitive abilities. In P. Green, M. Ford, \& G. Flamer (Eds.), Measurement and Piaget (pp. 198-204). New York: McGraw-Hill.

Fogelman, K. R. (1970). Piagetian tests for the primary school. London: National Foundation for Educational Research in England and Wales.

Gallagher, J. M., \& Reid, H. (1981). The learning theory of Piaget and Inhelder. Monterey, CA: Brooks/Cole Publishing.

Ginsburg, H., \& Opper, S. (1979). Piaget's theory of intellectual development. Englewood Cliffs, NJ: Prentice-Hall, Inc.

Krulik, S., \& Rudnik, J. A. (1987). Problem solving: A handbook for teachers. MA: Allyn and Bacon, Inc.

Lester, F. K. (1980). Research in mathematical problem-solving. In R. Shumway (Ed.), Research in mathematics education (pp. 286-323). Reston, VA: NCTM.

Lester, F. K. (1985). Methodological considerations in research on mathematical problem-solving instruction. In E. Silver (Ed.), Teaching and learning mathematical problem-solving: Multiple research perspectives (pp. 41-67). Hillsdale, NJ: Lawrence Eribuam.

Lovell, K. (1964). The growth of basic mathematical and scientific concepts in children. Warwick Square, London: University of London Press.

Lowery et al. (1986). It's the thought that counts. Palo Alto, CA: Dale Seymour Publications.

Mayer, R. E. (1977). Thinking and problem solving. Glenview, IL: Scott, Foresman. 
McLeod, D. B. (1985). Affective issues in research on teaching mathematical problem solving. In E. Silver (Ed.), Teaching and learning mathematical problem solving: Multiple research perspectives (pp. 267-279). Hillsdale, NJ: Lawrence Eribuam.

McLeod, D. B. (1988). Affective issues in mathematical problemsolving: Some theoretical considerations. Journal for Research in Mathematics Education, 19(2), 134-141.

National Assessment of Educational Progress. (1983). The third national mathematics assessment: Results, trends, and issues. Denver, CO: Educational Commission of the States.

National Council of Teachers of Mathematics. (1989). Curriculum and evaluation standards for school mathematics. Reston, VA: NCTM.

National Council of Teachers of Mathematics. (1980). An agenda for action: Recommendations for school mathematics of the 1980s. Reston, VA: The Council.

National Council of Teachers of Mathematics. (1968). More topics in mathematics for elementary school teachers (30th Year Book). Reston, VA: The Council.

Nesher, P., Greeno, J. G., \& Riley, M. S. (1982). The development of semantic categories for addition and subtraction. Educational Studies in Mathematics, $13,373-394$.

Neufeld, E. (1976). The philosophy of Jean Piaget and its education implications. NJ: General Learning Press.

Peterson, P. L., Carpenter, T., \& Fennema, E. (1989). Teachers' knowledge of students' knowledge in mathematics problem solving: Correlational and case analyses. Journal of Educational Psychology, 4, 558-569.

Piaget, J. (1964). Cognitive development in children: Piaget, development and learning. Journal of Research in Science Teaching, 2. $176-181$. 
Piaget, J. (1968). Six psychological studies. New York: Random House.

Piaget, J. (1970). Genetic Epistemology (Duckworth, Trans.). New York: Columbia University Press.

Polya, G. (1981). Mathematical Discovery. New York: John Wiley \& Sons.

Pulaski, M. S. (1971). Understanding Piaget: An introduction to children's cognitive development. New York: Harper \& Row.

Riley, M. S., Greeno, J. G., \& Heller, J. I. (1983). Development of children's problem-solving ability in arithmetic. In H. P. Ginsburg (Ed.), The development of mathematical thinking. New York: Academic Press.

Schoenfeld, A. H. (1987). Cognitive science and mathematics education. Hillsdale, NJ: Lawrence Eribaum.

Schoenfeld, A. H. (1985). Metacognitive and epistemological issues in mathematics understanding. In E. A. Silver (Ed.) Teaching and learning mathematical problem solving: Multiple research perspectives. Hillsdale, NJ: Lawrence Eribaum Associates.

Schoenfeld, A. H. (1982). Some thoughts on problem solving research and mathematics education. In F. K. Lester, \& J. Garofalo (Eds.), Mathematical problem solving: Issues in research (pp. 25-53). Philadelphia, PA: Franklin Institute Press.

Siegler, R. S. (1989). How children discover new strategies. Hillsdale, NJ: Lawrence Eribaum.

Silver, E. (Ed.). (1985). Teaching and learning mathematical problem solving: Multiple research perspectives. Hillsdale, NJ: Lawrence Eribaum. 
Simon, H. A. (1980). Problem solving and education. In D. T. Tuma, \& R. Reif (Eds.), Problem solving and education: Issues in teaching and research (pp. 81-96). Hillsdale, NJ: Lawrence Eribaum Associates.

Skemp, R. (1978). Relational understanding and instructional understanding. Arithmetic teacher, pp. 9-15.

Stanic, G. M., \& Kilpatrick, J. (1988). Historical perspectives on problem solving in the mathematics curriculum. In Charles \& Silver (Eds.) The teaching and assessing of mathematical problem solving. Reston, VA; NCTM.

Stevenson, H. W. (1975). Learning and cognition. In J. N. Payne (Ed.) Mathematics learning in early childhood. Thirty-seventh Yearbook of the National Council of Teachers of Mathematics. Reston, VA: The Council.

Wadsworth, B. J. (1984). Piaget's theory of cognitive and affective development. New York: Longman, Inc.

Walonick Association, Inc. State Pac Gold (Version 3.0). (1988). Minneapolis, MN: Author. 


\section{APPENDICES}


Appendix A

A Point System for Scoring Written Work

(Charles \& Lester, 1984)

Understanding the problem:

0 - Completely misinterprets the problem.

1 - Misinterprets part of the problem.

2 - Completely understands the problem.

Choosing and Implementing a Solution Strategy:

0 - Makes no attempt or uses a totally inappropriate strategy.

1 - Chooses a partly correct strategy based on interpreting part of the problem correctly.

2 - Chooses a strategy that could lead to a correct solution if used without error.

Getting an Answer:

0 - Gets no answer or a wrong answer based on an inappropriate solution strategy.

1 - Makes copying error or computational error, gets partial answer for a problem with multiple answers, or labels answer incorrectly. 2 - Gets correct solution. 
PLEAse nOte

Copyrighted materials in this document have not been filmed at the request of the author. They are available for consultation, however, in the author's university library.

Process Problems

62-67

Solution of Process Problems by Subject 9 68-73

University Microfilms International 
Appendix D

Summary of Statistics $(N=18)$

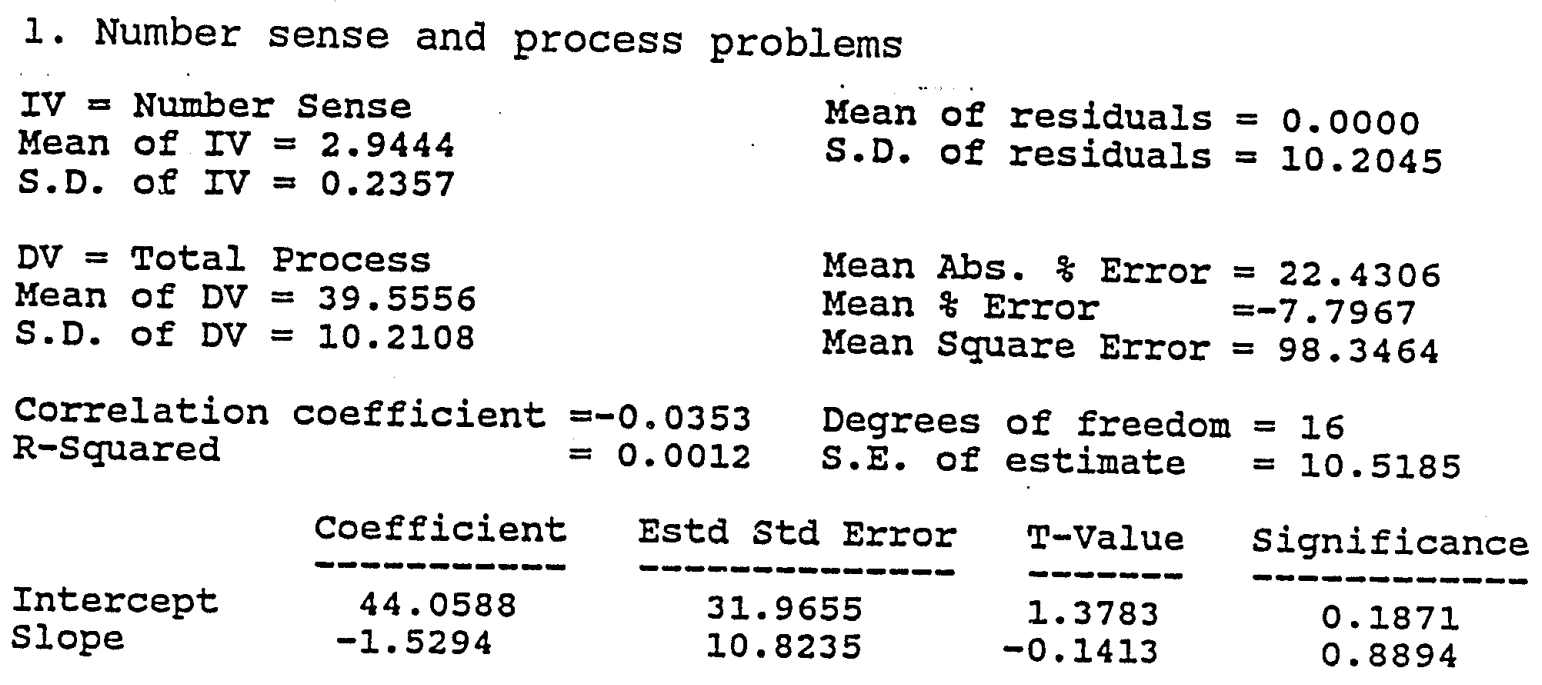

2. Logic operation and process problems

$$
\begin{aligned}
& \text { IV }=\text { Logic } \\
& \text { Mean of IV }=2.8333 \\
& \text { S.D. of IV }=0.5145 \\
& \text { DV = Total Process } \\
& \text { Mean of DV }=39.5556 \\
& \text { S.D. of DV }=10.2108
\end{aligned}
$$$$
\text { Correlation coefficient }=0.1306
$$$$
\text { R-Squared }
$$$$
=0.0171
$$

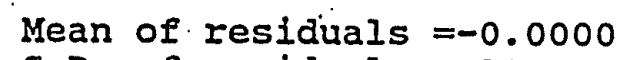

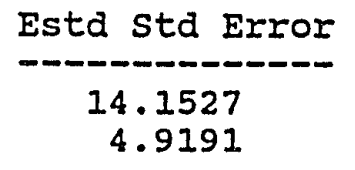

T-Value - -

2. 2759

0.5271
Significance

0.0370

0.6054 
3. Spatial concepts and process problems IV = 'spatial

Mean of IV $=1.7778$

S.D. of IV $=0.7321$

Mean of residuals $=-0.0000$

S.D. of residuals $=10.1778$

$\mathrm{DV}=$ Total Process

Mean of $\mathrm{DV}=39.5556$

S.D. of $\mathrm{DV}=10.2108$

Mean Abs. \& Error $=21.7698$

Mean \& Error $=-7.6908$

Correlation coefficient $=0.0804$

Mean Square Error $=97.8320$

R-Squared

$=0.0065$

Degrees of freedom $=16$

S.E. of estimate $=10.4910$

$\begin{array}{lcccc} & \text { Coefficient } & \text { Estd Std Error } & \text { T-Value } & \text { Significance } \\ \text { Intercept } & 37.5610 & 6.6553 & 5.6438 & 0.0000 \\ \text { Slope } & 1.1220 & 3.4756 & 0.3228 & 0.7510\end{array}$

4. Seriation and process problems

$I V=$ seriation

Mean of $I V=3.7222$

S.D. of IV $=1.4874$

DV $=$ Total Process

Mean of DV $=39.5556$

S.D. of $\mathrm{DV}=10.2108$

Correlation coefficient $=0.3942$

R-Squared

$=0.1554$
Mean of residuals $=-0.0000$

S.D. of residuals $=9.3841$

Mean Abs. \& Error $=22.1384$

Mean $\frac{7}{8}$ Error $\quad=-6.8584$

Mean Square Error $=83.1682$

Degrees of freedom $=16$

S.E. of estimate $=9.6729$

$\begin{array}{lcccc} & \text { Coefficient } & \text { Estd Std Error } & \text { T-Value } & \text { Significance } \\ \text { Intercept } & 29.4830 & 6.2980 & 4.6813 & 0.0003 \\ \text { Slope } & 2.7061 & 1.5772 & 1.7157 & 0.1055\end{array}$

5. Conservation of weight and process problems

IV = Conservation Weight

Mean of IV $=1.6667$

S.D. of IV $=0.7670$

Mean of residuals $=0.0000$

S.D. of residuals $=9.1407$

$\mathrm{DV}=$ Total Process

Mean of DV $=39.5556$

S.D. of $\mathrm{DV}=10.2108$

Mean Abs. \& Error $=21.1655$

Mean \& Error $=-6.1976$

Mean Square Error $=78.9111$

Correlation coefficient $=0.4457$

R-Squared

$=0.1986$

Degrees of freedom $=16$
S.E. of estimate $=9.4220$

$\begin{array}{lcccc} & \text { Coefficient } & \text { Estd Std Error } & \text { T-Value } & \text { Significance } \\ \text { Intercept } & 29.6667 & 5.4398 & 5.4536 & 0.0001 \\ \text { Slope } & 5.9333 & 2.9795 & 1.9914 & 0.0638\end{array}$


6. Conservation of volume and process problems $I V=$ Conservation Volume

Mean of IV $=2.0000$

S.D. of IV $=1.1882$

Mean of residuals $=-0.0000$

S.D. of residuals $=8.7591$

$D V=$ Total Process

Mean of $\mathrm{DV}=39.5556$

S.D. of $D V=10.2108$

Mean Abs. \& Error $=18.8335$

Mean \& Error $=-5.6975$

Correlation coefficient $=0.5139$

Mean Square Error $=72.4599$

R-Squared

$=0.2641$

Degrees of freedom $=16$

S.E. of estimate $=9.0287$

$\begin{array}{lcccc} & \text { Coefficient } & \text { Estd Std Error } & \text { T-Value } & \text { Significance } \\ \text { Intercept } & 30.7222 & 4.2562 & 7.2183 & 0.0000 \\ \text { Slope } & 4.4167 & 1.8430 & 2.3965 & 0.0291\end{array}$

7. Conservation of length and process problems

$I V=$ Conservation Length

Mean of IV $=1.8333$

S.D. of $I V=0.8575$

Mean of residuals $=0.0000$

S.D. of residuals $=8.2015$

$\mathrm{DV}=$ Total Process

Mean of DV $=39.5556$

S.D. of DV $=10.2108$

Mean Abs. \& Error $=20.0893$

Mean \& Error $\quad=-5.5669$

Mean Square Error $=63.5279$

Correlation coefficient $=0.5957$ Degrees of freedom $=16$

$\mathrm{R}$-Squared $=0.3548 \mathrm{~S} . \mathrm{E}$. of estimate $=8.4539$

$\begin{array}{lcccc} & \text { Coefficient } & \text { Estd Std Error } & \text { T-Value } & \text { Significance } \\ \text { Intercept } & 26.5511 & -1.8154 & 5.5138 & 0.0000 \\ \text { Slope } & 7.0933 & 2.3911 & 2.9665 & 0.0091\end{array}$

8. Total Piagetian tasks scores and process problems

IV = Total Piaget Tasks

Mean of IV $=16.7778$

S.D. of IV $=3.3353$

DV $=$ Total Process

Mean of $\mathrm{DV}=39.5556$

S.D. of $D V=10.2108$

Correlation coefficient $=0.6498$

R-Squared

$=0.4223$
Mean of residuals $=0.0000$

S.D. of residuals $=7.7611$

Mean Abs. \& Error $=17.9455$

Mean of Error $=-4.7454$

Mean Square Error $=56.8877$

Degrees of freedom $=16$

S.E. of estimate $=7.9999$

$\begin{array}{lcccc} & \text { Coefficient } & \text { Estd Std Error } & \text { T-Value } & \text { Significance } \\ \text { Intercept } & 6.1774 & -9.9407 & 0.6214 & 0.5431 \\ \text { Slope } & 1.9894 & 0.5817 & 3.4198 & 0.0035\end{array}$

